\title{
Conditional Deletion of the Prolactin Receptor Reveals Functional Subpopulations of Dopamine Neurons in the Arcuate Nucleus of the Hypothalamus
}

\author{
Rosemary S.E. Brown, ${ }^{1,2}$ Ilona C. Kokay, ${ }^{1,2}$ Hollian R. Phillipps, ${ }^{1,2}$ (ESiew Hoong Yip, ${ }^{1,2}$ Papillon Gustafson, ${ }^{1,2}$ \\ (1)Amanda Wyatt, ${ }^{1,2}$ Caroline M. Larsen, ${ }^{1,2}$ Penelope Knowles, ${ }^{1,2}$ Sharon R. Ladyman, ${ }^{1,2}$-Paul LeTissier, ${ }^{3}$ \\ and $\odot$ David R. Grattan ${ }^{1,2,4}$ \\ ${ }^{1}$ Centre for Neuroendocrinology and ${ }^{2}$ Department of Anatomy, Otago School of Medical Sciences, University of Otago, Dunedin 9054, New Zealand, ${ }^{3}$ Centre \\ for Integrative Physiology, University of Edinburgh, Edinburgh EH8 9YL, United Kingdom, and ${ }^{4}$ Maurice Wilkins Centre for Molecular Biodiscovery, \\ New Zealand
}

Tuberoinfundibular dopamine (TIDA) neurons, known as neuroendocrine regulators of prolactin secretion from the pituitary gland, also release GABA within the hypothalamic arcuate nucleus. As these neurons express prolactin receptors (Prlr), prolactin may regulate GABA secretion from TIDA neurons, potentially mediating actions of prolactin on hypothalamic function. To investigate whether GABA is involved in feedback regulation of TIDA neurons, we examined the physiological consequences of conditional deletion of Prlr in GABAergic neurons. For comparison, we also examined mice in which Prlr were deleted from most forebrain neurons. Both neuron-specific and GABA-specific recombination of the Prlr gene occurred throughout the hypothalamus and in some extrahypothalamic regions, consistent with the known distribution of Prlr expression, indicative of knock-out of Prlr. This was confirmed by a significant loss of prolactininduced phosphorylation of STAT5, a marker of prolactin action. Several populations of GABAergic neurons that were not previously known to be prolactin-sensitive, notably in the medial amygdala, were identified. Approximately $50 \%$ of dopamine neurons within the arcuate nucleus were labeled with a GABA-specific reporter, but Prlr deletion from these dopamine/GABA neurons had no effect on feedback regulation of prolactin secretion. In contrast, Prlr deletion from all dopamine neurons resulted in profound hyperprolactinemia. The absence of coexpression of tyrosine hydroxylase, a marker for dopamine production, in GABAergic nerve terminals in the median eminence suggested that rather than a functional redundancy within the TIDA population, the dopamine/GABA neurons in the arcuate nucleus represent a subpopulation with a functional role distinct from the regulation of prolactin secretion.

Key words: arcuate nucleus; conditional knock-out; GABA; prolactin receptor; tuberoinfundibular dopamine neurons

\section{Significance Statement}

Using a novel conditional deletion of the prolactin receptor, we have identified functional subpopulations in hypothalamic dopamine neurons. Although commonly considered a uniform population of neuroendocrine neurons involved in the control of prolactin secretion, we have shown that approximately half of these neurons express GABA as well as dopamine, but these neurons are not necessary for the feedback regulation of prolactin secretion. The absence of tyrosine hydroxylase in GABAergic nerve terminals in the median eminence suggests that only the non-GABAergic dopamine neurons are involved in the control of pituitary prolactin secretion, and the GABAergic subpopulation may function as interneurons within the arcuate nucleus to regulate other aspects of hypothalamic function.

\section{Introduction}

Inappropriately elevated levels of the pituitary hormone prolactin have serious adverse consequences, notably infertility and metabolic disorders (Capozzi et al., 2015), and possibly cancer (Bernard et al., 2015). To prevent aberrant hyperprolactinemia, prolactin secretion is tonically inhibited by dopamine produced 
from the tuberoinfundibular dopamine (TIDA) neurons in the hypothalamic arcuate nucleus (Freeman et al., 2000; Grattan, 2015; Grattan and LeTissier, 2015). A short-loop feedback system functions such that even small elevations in prolactin induce a robust increase in dopamine release. Most TIDA neurons express the prolactin receptor (Prlr) (Lerant and Freeman, 1998; Grattan, 2001; Kokay and Grattan, 2005) and respond to increased prolactin both with a rapid increase in electrophysiological activity (Brown et al., 2012; Lyons et al., 2012; Romanò et al., 2013), and activation of several signal transduction pathways (Grattan et al., 2001; Ma et al., 2005a, b). Collectively, these actions promote both the synthesis and secretion of dopamine (Grattan and LeTissier, 2015). Mice lacking the dopamine D2 receptor are profoundly hyperprolactinemic due to loss of dopaminergic inhibition in the pituitary gland (Kelly et al., 1997; Saiardi et al., 1997). Prlr knock-out mice and mice with impaired Prlr signaling also show chronically elevated prolactin secretion due to impaired activation of TIDA neurons (Binart et al., 2000; Grattan et al., 2001; Kelly et al., 2001). Similar hyperprolactinemia has recently been observed in humans with an inactivating mutation of the Prlr (Newey et al., 2013), suggesting that this homeostatic feedback system is conserved among mammals.

While circulating prolactin is maintained at low levels in males and nonpregnant females, elevated prolactin must occur under appropriate conditions, such as pregnancy and lactation. These physiological elevations of prolactin are facilitated by marked changes in the function of the feedback system. Despite early reports that TIDA neurons become unresponsive to prolactin during lactation (Demarest et al., 1983; Arbogast and Voogt, 1996), we have demonstrated that prolactin continues to stimulate the firing of these cells, but functional suppression of prolactin is lost because the neurons no longer acutely release dopamine in response to prolactin (Romanò et al., 2013). The dissociation of dopamine release from ongoing prolactin stimulation of the electrical activity suggests that these neurons might continue to mediate other actions of prolactin in the hypothalamus, distinct from secretion of dopamine into the pituitary portal blood. It is known that TIDA neurons coexpress GABA (Everitt et al., 1984; Meister and Hökfelt, 1988), and recent evidence suggests that, in addition to the neuroendocrine projection to the median eminence, these neurons also exhibit extensive local projections and release GABA to regulate neuronal circuits within the arcuate nucleus (Zhang and van den Pol, 2015). Hence, prolactin might regulate GABA secretion from TIDA neurons, potentially mediating some of the broad actions of prolactin on hypothalamic function during lactation (Grattan and Kokay, 2008).

To investigate whether GABA might be involved in feedback regulation of TIDA neurons, we have examined the physiological consequences of conditional deletion of Prlr in GABAergic neurons using a novel mouse line with loxP sites flanking the Prlr gene $\left(P r l r^{l o x} / l o x\right)$ crossed with mice expressing Cre-recombinase (Cre) under the control of the vesicular GABA transporter (VGat) (Vong et al., 2011). For comparison, we also examined mice in which Prlr were deleted from most forebrain neurons. Surprisingly, the data revealed functional subpopulations of prolactin-sensitive dopamine neurons in the arcuate nucleus. Approximately half of the dopamine cells in the arcuate nucleus coexpress GABA, but these dopamine/GABA neurons are not required for the normal regulation of prolactin secretion and therefore may mediate other functions of prolactin in the arcuate nucleus.

\section{Materials and Methods}

Animals and tissue collection. Prlr ${ }^{\text {lox/lox }}$ mice were generated on a C57BL/6 background by Ozgene (Pty), using a conditional knock-in strategy in which essential wild-type sequence would be replaced by an enhanced green fluorescent protein (eGFP) reporter sequence via Cre-mediated inversion of a region flanked by lox66 and lox71 sites (Zhang and Lutz, 2002; Oberdoerffer et al., 2003). Our aim was to establish a conditional knock-out of exons 5-10 of the Prlr gene, equivalent to the original global knock-out of the Prlr (Ormandy et al., 1997). Using mRNA/cDNA sequences corresponding to the Prlr gene (NCBI database; GenBank accession number(s) NM_011169, BC006652; annotated genomic sequence Ensembl gene report ID: ENSMUSG00000005268), the targeting vector was constructed by PCR from four fragments: a 5' homology arm, a 3'homology arm, a wild-type arm, and a splice acceptor::reporter fusion arm (which included exon 5 splice acceptor sequence). The homology arms were $\sim 6 \mathrm{~kb}$ in length. The targeting vector included a PGKneo selection cassette that was flanked by FRT sites. Gene targeting was confirmed by Southern blotting using $5^{\prime}$ - and $3^{\prime}$-probes located both inside and outside the targeting vector. Completed constructs were electroporated into C57BL/6 embryonic stem cells, and then chimeric mice were generated using standard homologous recombination and blastocyst manipulation techniques, as part of the contracted service by Ozgene. Chimeric mice were bred to C57BL/6 mice to identify germ-line transmission of the targeted gene; then the PGKneo cassette was deleted by crossing with FLPe recombinase deleter mice. Mice were then transferred to the University of Otago animal facility, and the FLP was removed by

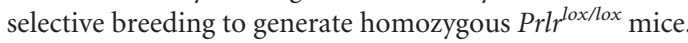

The construct was designed such that the wild-type exon 5 and the inverted eGFP reporter were flanked by lox66 and lox71 sites. In the absence of Cre, splicing to exon 5 occurred normally, as the heterologous splicing signals surrounding the fusion arm were not recognized because they were in an inverted orientation. Cre-mediated recombination between the lox66 and lox71 sites resulted in the inversion of the sequence between these sites, generating one loxP site and one double-mutant lox site (loxDM). In the inverted locus, splicing included the SA::reporter but excluded the now inverted wild-type exon, with transcription stopping at the poly-A sequence resulting in expression of eGFP and deletion of exons 5-10 of the Prlr gene. This eliminates the entire transmembrane and intracellular portions of the receptor, resulting in a complete absence of both long and short forms of the Prlr in targeted tissues that express Cre.

Female Prlr ${ }^{l o x / l o x}$ mice were crossed with male mice expressing Crerecombinase (Cre) using an internal ribosome entry site under the control of the VGat promoter (referred to here as VGat-Cre) (Vong et al., 2011). For comparison, we also examined mice in which Prlr were deleted from most forebrain neurons using Cre expression driven by the neuron-specific calcium/calmodulin-dependent protein kinase II $\alpha$ (CamK-Cre) (Casanova et al., 2001). Heterozygous offspring from these matings were then backcrossed to homozygous Prlr ${ }^{l o x / l o x}$ mice, generating mice that were homozygous for Prlr ${ }^{\text {lox/lox }}$, and either expressed Cre in most neurons (CamK-Cre-positive; neuron-specific Prlr KO) or specifically in GABAergic neurons (VGat-Cre-positive), or did not express Cre (Cre-negative; controls). As Cre-mediated inversion deleted the Prlr gene and knocked in eGFP in its place, eGFP expression in the brain could be used as a marker for both successful recombination and for the normal pattern of receptor expression.

Genotypes of Prlr lox/lox mice were determined by PCR. The presence of the wild-type Prlr allele was detected by primer 1 ( $5^{\prime}$-TGT CCA GAC TAC AAA ACC AGT GGC-3') and primer 2 ( $5^{\prime}$-CAG TGC TCT GGA GAG CTG GC-3'), which span the Lox71 site subsequent to exon 5 and amplify a 546 bp product from wild-type mice but not from $\mathrm{Prlr}$ lox/lox mice. Mice carrying a $P r l r^{l o x} / l o x$ allele were identified using primer 1 and primer 3 ( $5^{\prime}$-ACC TCC CCC TGA ACC TGA AAC ATA A-3'). Primer 3 is located within the inverted GFP sequence and thus only produces a $\sim 400$ bp band from mice heterozygous or homozygous for the Prlr lox/lox allele, whereas no band is generated from wild-type mice. The presence or absence of CamK-Cre was determined using primers creP1 (5'-GGT TCT CCG TTT GCA CTC AGG-3'), creP3 (5'-CTG CAT GCA CGG 
GAC AGC TCT- $\left.3^{\prime}\right)$, and $\mathrm{creP}^{\prime}$ ( ( $^{\prime}$-GCT TGC AGG TAC AGG AGG TAG T- $\left.3^{\prime}\right)$. CreP1 and creP3 span the start site of the endogenous CaMKII $\alpha$ gene locus and produce a 285 bp band in wild-type animals only. CreP17 anneals within the inserted cre sequence at the modified CaMKII $\alpha$-cre gene locus to generate a 380 bp product with creP1, but only in mice with at least one copy of this Cre construct.

Additional reporter strains of mice were generated by crossing the VGat-Cre mice with animals homozygous for the Ai9 Cre-dependent tdTomato reporter (Jackson ImmunoResearch Laboratories B6.Cg-

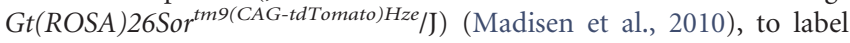
GABAergic neurons, and dopamine transporter internal ribosome entry site-Cre mice (DAT-Cre) (Jackson ImmunoResearch Laboratories, B6.SJL-Slc6a3 ${ }^{\text {tm 1.1(cre)Bkmn} / J) ~(B a ̈ c k m a n ~ e t ~ a l ., ~ 2006) ~ w i t h ~ m i c e ~ h o m o z y-~}$ gous for a Cre-dependent tauGFP reporter (ROSA26-CAGS- $\tau$ GFP, a gift from Ulrich Boehm) (Wen et al., 2011) to label dopaminergic neurons.

Mice were used at ages 8-14 weeks (weighing 20-25 g), and were initially group-housed under conditions of controlled temperature $\left(22 \pm 1^{\circ} \mathrm{C}\right)$ and lighting $(12 \mathrm{~h} \mathrm{light}, 12 \mathrm{~h}$ dark cycles, with lights on at 6:00 A.M.) with ad libitum access to food and water. The estrous cycle in female mice was monitored by daily collection of vaginal smears, and cycles were followed for up to 3 weeks. Some animals were killed in the morning for assessment of plasma prolactin concentration by radioimmunoassay. Further groups of female mice were individually housed with a wild-type C57BL/ 6 adult male and monitored daily for the presence of a sperm plug. The presence of a plug was counted as day 1 of pregnancy, males were removed, and the day of parturition was recorded.

To assess changes in serum prolactin concentration in response to acute stress (a potent stimulator of prolactin secretion) (Van de Kar and Blair, 1999), 3 groups of GABA-specific Prlr KO (Prlr ${ }^{\text {lox } / l o x} /$ VGat-Cre) and Cre-negative control $\left(\right.$ Prll $^{l o x} /$ lox $)$ mice were used $(n=6$ or 7$)$. One group of mice were killed by decapitation and trunk blood collected for baseline measurement of prolactin. A second group received a period of restraint stress using a conical plastic bag that completely restricted their movement while allowing breathing through a small hole (DecapiCone, Braintree Scientific). After 15 min of restraint, mice were decapitated and trunk blood was immediately collected. A third group received 15 min of restraint stress and were returned to their home cage for $15 \mathrm{~min}$ of recovery before blood collection by decapitation.

All experimental procedures were approved by the University of Otago Animal Ethics Committee, in compliance with the New Zealand Animal Welfare Act (1999).

Immunohistochemistry. We have previously shown that the immunohistochemical labeling of prolactin-induced phosphorylated signal transducer and activator of transcription 5 (pSTAT5) is a reliable and sensitive marker for prolactin-responsive neurons (Brown et al., 2010, 2011). For investigating acute prolactin responses, the following groups of virgin mice were administered with ovine prolactin $(5 \mathrm{mg} / \mathrm{kg}$ injection/i.p., $45 \mathrm{~min}$ before perfusion); neuron-specific Prlr KO mice $\left(\right.$ Prlr $^{\text {lox } / l o x} /$ CamK-Cre; $\left.n=4-6\right)$, GABA-specific Prlr KO mice $\left(\right.$ Prlr $^{\text {lox/lox } / V G a t-C r e ; ~} n=4$ or 5$)$, and Cre-negative control mice $\left(P r l r^{l o x / l o x} ; n=5-7\right)$. Mice were anesthetized with sodium pentobarbital and perfused transcardially with $4 \%$ PFA. Brains were removed, postfixed for $1 \mathrm{~h}$ in the same fixative, and cryoprotected in $30 \%$ sucrose overnight. Two sets of $30-\mu \mathrm{m}$-thick coronal sections through the forebrain from each animal were cut using a sliding microtome. One series of tissue was each used to examine pSTAT5 and eGFP expression (indicating successful recombination in the Prlr lox/lox mice, and therefore, representing cells that expressed Prlr before recombination) in the forebrain, by chromagen immunohistochemistry. Tissue from further groups of $\operatorname{Prlr}^{\text {lox/lox }}(n=6$ or 7$)$, Prlr ${ }^{\text {lox/lox }} /$ CamK-Cre $(n=6)$, and Prlr ${ }^{\text {lox/lox} / V G a t-C r e ~}(n=7)$ animals was also generated to label TH (an established marker of dopamine neurons in the hypothalamus) and pSTAT5 by chromagen dual-label immunohistochemistry. Sets of tissue were also collected from VGat-Cre/td-tomato and $\mathrm{Prlr}^{\text {lox/lox} / V G a t-C r e / t d-t o m a t o ~ m i c e ~ f o r ~ i m m u n o f l u o r e s c e n t ~ l a b e l i n g ~ o f ~}$ pSTAT5 (marker of prolactin-responsive cells), endogenous td-tomato expression (marker of GABA neurons by reporting VGat-Cre expression), and either TH or eGFP.
Immunohistochemistry for pSTAT5 was conducted as previously described (Brown et al., 2010). Briefly, an antigen retrieval procedure was performed on all tissue before immunohistochemistry for pSTAT5. Sections were incubated in rabbit anti-pSTAT5 primary antibody (polyclonal rabbit anti-phospho-STAT5, Tyr 694, 1:1000 for chromagen immunohistochemistry, 1:500 for immunofluorescence, Cell Signaling Technology), for $72 \mathrm{~h}$ at $4^{\circ} \mathrm{C}$. To label GFP, sections were incubated in either polyclonal rabbit-anti GFP (1: 10 000, Invitrogen, A-6455) for chromagen immunohistochemistry or chicken anti-GFP (GFP-1020: 10 000, Aves Laboratories) for immunofluorescence. For pSTAT5 and GFP labeling by chromagen immunohistochemistry, sections were incubated for $90 \mathrm{~min}$ in biotinylated goat anti-rabbit IgG (1:200; Vector Laboratories), followed by a $90 \mathrm{~min}$ incubation in Vector Elite avidin-biotin-HRP complex (1:100). Peroxidase labeling was visualized with nickeldiaminobenzidine tetrahydrochloride using glucose oxidase to create a black, nuclear precipitate. For immunofluorescent labeling of pSTAT5, sections were incubated in biotinylated goat anti-rabbit IgG for $90 \mathrm{~min}$, followed by a $90 \mathrm{~min}$ incubation in either Streptavidin 488 or 647 IgG (1:200, AlexaFluor, Invitrogen). For immunofluorescent labeling of GFP, sections were incubated in goat anti-chicken 488 IgG (1:200, AlexaFlour, Invitrogen). Quantification of pSTAT5 labeling was conducted on chromagen-labeled tissue, with the total number of pSTAT5-labeled nuclei counted in 2 sections per animal in the anteroventral periventricular (AVPV), medial preoptic nucleus (MPN), arcuate (Arc), ventromedial hypothalamic (VMN), and medial amygdala (MEA): bregma coordinates $\sim 0.26,0.02,-1.70$ (Arc and VMN) and $-2.06 \mathrm{~mm}$ for these regions, respectively. Sections were anatomically matched between each different animal, and data are reported as mean \pm SEM.

To dual-label TH and pSTAT5 by chromagen immunohistochemistry, sections were first labeled for PSTAT5, before being incubated with a polyclonal rabbit anti-TH primary antibody (AB152, 1: 5000; Millipore) for $48 \mathrm{~h}$ at $4^{\circ} \mathrm{C}$. Sections were incubated for $4 \mathrm{~h}$ in peroxidase-labeled goat antirabbit IgG (1:200; Vector Laboratories), and peroxidase labeling was visualized with diaminobenzidine tetrahydrochloride (brown cytoplasmic staining). The total number of TH-labeled cells and the total number of TH-labeled cells expressing pSTAT5 were counted in two sections per animal in the arcuate nucleus. Sections were anatomically matched between each different animal, at bregma coordinate of $\sim-1.70$. For immunofluorescent labeling of TH, tissue was first incubated in goat anti-mouse IgG to block endogenous mouse IgG (Unconjugated AffiniPure Fab Fragment, 1:100; Jackson ImmunoResearch Laboratories) for $12 \mathrm{~h}$ at $4^{\circ} \mathrm{C}$. Sections were then incubated in monoclonal mouse anti-TH primary antibody (MAB 318, 1:1000, Millipore) for $12 \mathrm{~h}$ at $4^{\circ} \mathrm{C}$, before a $90 \mathrm{~min}$ incubation in goat anti-mouse $647 \mathrm{IgG}$ (1:500, AlexaFluor, Invitrogen).

Combination in situ hybridization/immunohistochemistry. To detect Prlr mRNA in dopamine neurons, we used a combination of in situ hybridization of Prlr mRNA with immunohistochemistry for $\mathrm{TH}$. Groups of neuron-specific Prlr KO (Prlr ${ }^{l o x / l o x} /$ CamK-Cre) and Crenegative control $\left(\mathrm{Prlr}^{l o x / l o x}\right)$ mice were transcardially perfused with $2 \%$ PFA, brains removed and cryoprotected in $30 \%$ sucrose overnight. Sets of $16 \mu \mathrm{m}$ coronal sections were cut in a cryostat, and sections containing the arcuate nucleus were selected. Combination in situ hybridization/ immunohistochemistry was then performed. PCR-generated DNA templates were prepared using forward and reverse primers designed to target mRNA encoded by exons 6 and 7 of the Prlr gene (accession number NM 011169.3). The forward primer sequence was 5'-AGA GCC TCC TCG GAA CCT GACT-3', and the reverse primer sequence was $5^{\prime}$-GCT TGC AGC GAG TCT GGA CAAG 3'. T7 or SP6 promoter sequences were incorporated onto the ends of the primer nucleotide sequences, and a DNA template was generated from mouse brain RNA by PCR. The cDNA templates were then transcribed directly according to the manufacturer's instructions using in vitro transcription kit (Promega) and the appropriate polymerase. T7 RNA polymerase was used to produce an antisense 248 bp RNA probe labeled with $\left.\left[{ }^{35} \mathrm{~S}\right] \mathrm{UTP}\right)$. A sense probe was also made, using SP6 RNA polymerase. The probes were purified using Mini Quick spin columns (Roche Applied Science).

Brain sections were washed in $0.5 \times$ SCC $(75 \mathrm{~mm} \mathrm{NaCl}, 7.5 \mathrm{~mm}$ sodium citrate), incubated in proteinase $\mathrm{K}(2 \mu \mathrm{g} / \mathrm{ml})$, and acetylated with $0.25 \%$ acetic anhydride. Each slide was covered with $100 \mu$ l of hybridization 
buffer (100 mм DDT, $0.3 \mathrm{~m} \mathrm{NaCl}, 20$ mм Tris pH 8, 5 mм EDTA, $1 \times$ Denhardt's solution, $10 \%$ dextran sulfate, $50 \%$ formamide) and prehybridized for $2.5 \mathrm{~h}$ at $42^{\circ} \mathrm{C}$. Probes $\left(1.2 \times 10^{6} \mathrm{cpm} / \mathrm{section}\right)$ were denatured for $3 \mathrm{~min}$ at $95^{\circ} \mathrm{C}$ and pipetted in $20 \mu$ l of hybridization buffer onto sections. Sections were coverslipped before being incubated overnight at $55^{\circ} \mathrm{C}$, washed, and treated with ribonuclease A $(20 \mu \mathrm{g} / \mathrm{L})$ for $30 \mathrm{~min}$ at room temperature. Following a series of washes (most stringent, $2 \mathrm{~h}$ in $0.1 \times$ SCC buffer at $60^{\circ} \mathrm{C}$ ), TIDA neurons were identified by immunohistochemistry for $\mathrm{TH}$, using a polyclonal goat antirabbit primary antibody (AB151, 1:3000; Millipore). Peroxidase labeling was visualized with diaminobenzidine tetrahydrochloride using glucose oxidase to create a brown, cytoplasmic precipitate. Sections were washed in TBS buffer and briefly dipped in $70 \%$ ethanol, before being exposed to scientific imaging film (Kodak BioMax MR) for $6 \mathrm{~d}$ to generate autoradiograms. All slides were then coated with Ilford K.5D emulsion (Polysciences), placed in light-proof slide boxes containing desiccant, and stored at $4^{\circ} \mathrm{C}$. After 5 weeks, slides were developed in Kodak D19, fixed with Ilford Hypan, and dehydrated in graded ethanols then dried for $1 \mathrm{~h}$ at $42^{\circ} \mathrm{C}$. Sections were cleared in xylene and coverslipped with Vectamount mounting medium.

Dual-label in situ hybridization. To detect Prlr mRNA in GABAergic neurons, we used dual-label in situ hybridization, as described previously (Kokay et al., 2011). Primer pairs were designed for the Prlr mRNA, as described above, and for glutamic acid decarboxylase (GAD) using sequences from GenBank for Gad2 and Gad1 (accession numbers NM008078.2 and AF326547.1, respectively). cDNA templates that incorporated T7 and SP6 RNA polymerase sequence sites were then generated using PCR. The specificity of all the cDNA templates was confirmed by sequencing. ${ }^{35}$ S-labeled cRNA probes targeted to the Prlr mRNA were generated and antisense and sense cRNA probes for Gad1 and Gad2, labeled with digoxigenin, were transcribed from the cDNA templates using a digoxigenin RNA-labeling kit (Roche) and the appropriate polymerases. Unincorporated nucleotides were removed from all labeled probes with mini Quick Spin RNA purification columns (Roche).

Hybridization was performed as described above. Briefly, sections were permeabilized with proteinase $\mathrm{K}$, acetylated, and prehybridized in the hybridization solution without the labeled cRNA probes for 1-3 h. Sections were incubated for $16 \mathrm{~h}$ at $55^{\circ} \mathrm{C}$ with an ${ }^{35} \mathrm{~S}$-labeled RNA probe $\left(1.2 \times 10^{6} \mathrm{cpm}\right.$ per $120 \mu$ l of hybridization solution) complementary to Prlr together with the digoxigenin-labeled probes $(0.5 \mathrm{ng} / \mu \mathrm{l} / \mathrm{kb}$ per section) specific for Gad1 and Gad2 mRNA. Following hybridization, sections were washed, subjected to RNase treatment, followed by a series of washes (most stringent, $0.1 \mathrm{M} \mathrm{SSC}$ at $60^{\circ} \mathrm{C}$ with shaking for $2 \mathrm{~h}$ ). To visualize the digoxigenin-labeled mRNA hybrids, sections were incubated in sheep anti-digoxigenin antibody conjugated to alkaline phosphatase (1:2000 dilution) for $24 \mathrm{~h}$ at $4^{\circ} \mathrm{C}$, then detected using nitroblue tetrazolium/5-bromo-4-chloro-3-indolyl phosphate as a substrate. After air drying, slides were dipped in Ilford K.5D emulsion (Polysciences), sealed in light-proof boxes with desiccant, and stored at $4^{\circ} \mathrm{C}$ for $4-5$ weeks. Slides were developed, as above. To generate autoradiograms, the majority of slides were also apposed to film (Kodak BioMax MR) for 3-5 $\mathrm{d}$ before emulsion coating.

Radioimmunoassay. Trunk blood was collected, and serum mouse prolactin levels were measured in duplicate $10 \mu \mathrm{l}$ sample volumes by double-antibody radioimmunoassay as previously described (Brown et al., 2010). Data are expressed in terms of a mouse prolactin standard curve generated using National Institute of Diabetes and Digestive and Kidney Diseases mouse prolactin reference preparation for radioimmunoassay. The nonspecific binding of the assay was $2.7 \%$ and the "estimated dose" at $90 \%$ binding for the assay was $1.14 \mathrm{ng} / \mathrm{ml}$.

Statistical analysis. Data are mean \pm SEM, and all statistical analysis was undertaken using GraphPad Prism 6 (GraphPad). The number of estrous cycles between control and Cre-expressing groups were compared by unpaired $t$ tests. One-way ANOVAs were used to statistically compare the time taken from mating to presence of plug and gestation length between genotypes, and a Tukey post hoc test was used where appropriate. Statistical comparisons of serum mouse prolactin levels between Cre-expressing and control groups were performed by unpaired $t$ tests. For analyzing pSTAT5, $\mathrm{TH}$, and the colocalization of pSTAT5 and TH labeling, unpaired $t$ tests were performed for each region of the brain between control and cre-expressing groups. Stress-induced changes in serum prolactin levels were analyzed by a two-way ANOVA, and Tukey's multiple-comparison test was used to identify statistically significant changes.

\section{Results}

Profound hyperprolactinemia and prolonged estrous cycles in neuron-specific but not GABA neuron-specific Prlr KO mice

Neuron-specific Prlr KO (Prlr ${ }^{l o x} /$ lox $/$ CamK-Cre) mice had disrupted estrous cycles characterized by prolonged periods in diestrous $(0.29 \pm 0.18$ estrous cycles in $15 \mathrm{~d}$ compared with $2.29 \pm$ 0.29 in Cre negative controls; $\mathrm{t}(12)=5.88, p<0.001$, $t$ test; Fig. $1 A)$. Neuron-specific Prlr KO female mice on average required $24.95 \pm 4.52 \mathrm{~d}$ to display plugs from first mating with a wild-type C57BL/6J male, compared with $3.90 \pm 1.0 \mathrm{~d}$ for Cre negative $\left(\right.$ Prlr $\left.^{\text {lox } / l o x}\right)$ controls $\left(F_{(3,70)}=18.86, p<0.001\right.$; one-way ANOVA; Fig. $1 B)$. In contrast, GABA-specific Prlr KO ( $P r l r^{\text {lox/lox } / v G a t-C r e) ~}$ mice had normal estrous cycles (Fig. 1A), and normal fertility, taking only $2.5 \pm 0.63 \mathrm{~d}$ to display plugs following first mating $(p=0.99$; Fig. $1 B)$. Neither genotype showed any difference in mean gestation length compared with either C57BL/6J or Crenegative control mice $\left(F_{(3,67)}=1.749, p=0.165\right.$; one-way ANOVA; Fig. 1C). The neuron-specific Prlr KO mice also showed markedly elevated serum prolactin concentrations in both females $(516.6 \pm 61.1 \mathrm{ng} / \mathrm{ml})$ and males $(43.4 \pm 10.0 \mathrm{ng} / \mathrm{ml})$, compared with Cre-negative control mice $(131.8 \pm 31.4 \mathrm{ng} / \mathrm{ml}$ in females, $t(12)=5.61, p<0.001$, $t$ test; $19.1 \pm 5.1 \mathrm{ng} / \mathrm{ml}$ in males, $t(15)=2.01, p=0.027, t$ test; Fig. $1 D)$. Consistent with the absence of an effect on the estrous cycle, there was no change in serum prolactin concentration in GABA-specific Prlr KO mice, compared with Cre-negative control mice, in either males or females (Fig. 1D).

\section{Prlr-expressing cells are found throughout the basal forebrain, and neuron-specific deletion of Prlr using the CamK-Cre results in complete loss of Prlr expression on tuberoinfundibular dopaminergic neurons}

CamK-Cre-induced expression of eGFP could be detected by immunohistochemistry throughout the hypothalamus of neuronspecific Prlr KO mice (Fig. 2A). The expression of GFP was restricted to regions known to normally express Prlr, including the AVPV, MPN, VMN, and Arc nuclei, as well as some extra-hypothalamic regions, such as the bed nucleus of the stria terminalis and posterodorsal MEA. The induction of eGFP expression was accompanied by a significant loss of prolactin-induced PSTAT5 expression in the same regions, indicating functional removal of Prlr from a high proportion of neurons (Fig. $2 B, C$ ). Specifically within the arcuate nucleus, Prlr mRNA expression was completely absent from TIDA neurons, as identified using expression of TH protein, in neuronspecific Prlr KO mice (Fig. 2D). The inability of prolactin to exert negative feedback regulation of TIDA neurons in these mice would account for the observed hyperprolactinemia.

\section{Populations of prolactin-responsive GABAergic neurons are found throughout the basal forebrain}

As seen for the neuron-specific Prlr KO mice, vGat-Cre-induced expression of eGFP could be detected by immunohistochemistry throughout the forebrain of GABA-specific Prlr KO (Prlr ${ }^{\text {lox/lox}} /$ VGat-Cre) mice, suggesting that there are widespread populations of prolactin-responsive GABAergic neurons (Fig. $3 A$ ). Prolactin-responsive GABAergic neurons were observed in the AVPV, MPN, Arc, and MEA (Fig. 3A), although compared with the neuron-specific Prlr KO, the number of GFP labeled 
A
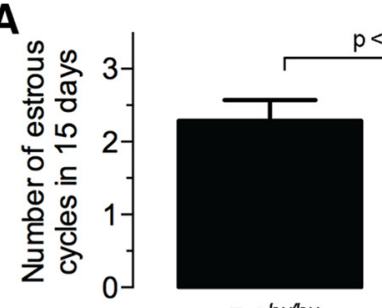

Prtrox/lox
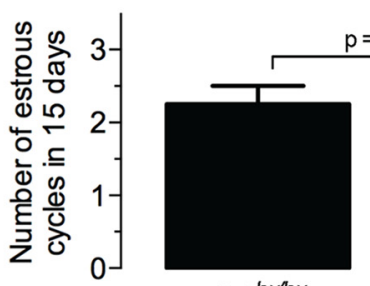

Prritoxibx

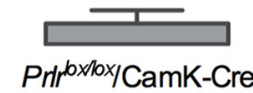

Prribxiox/CamK-Cre

$=0.548$

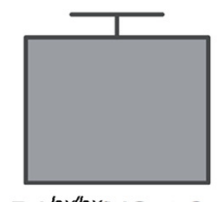

B

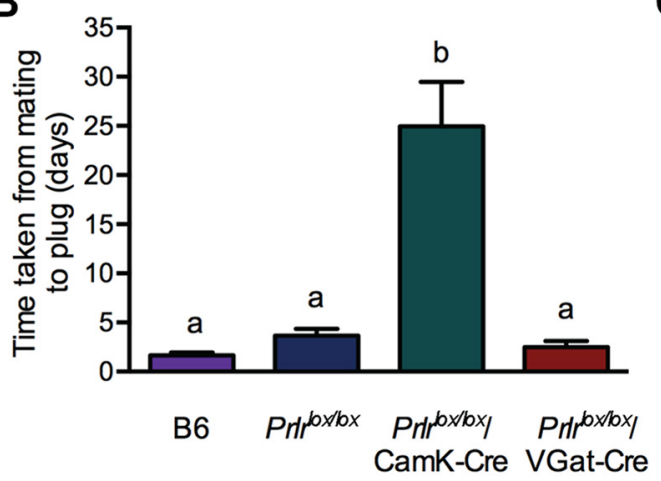

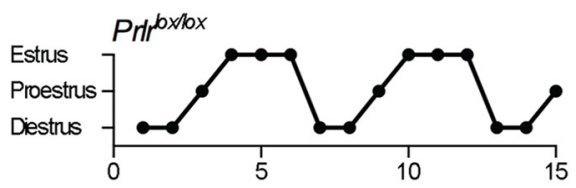
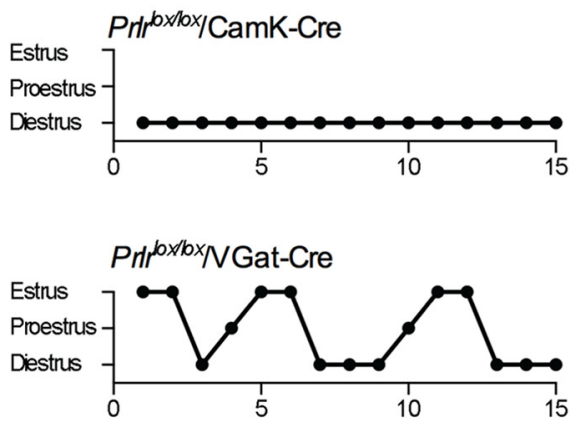

C

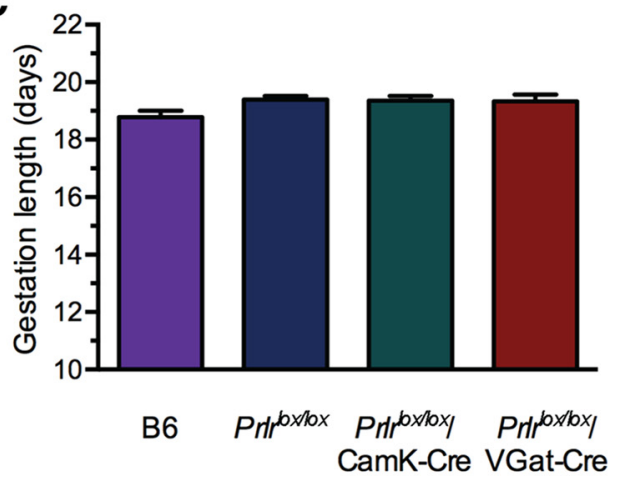

D

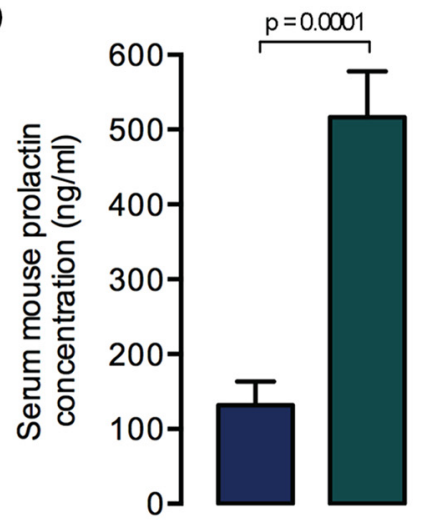

Females

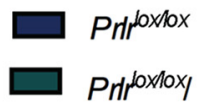

CamK-Cre

Males

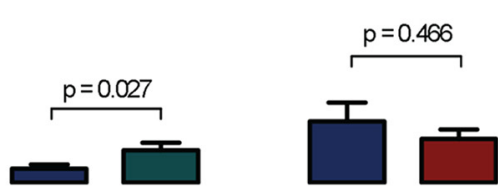

Females

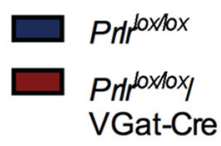

Gat-Cre

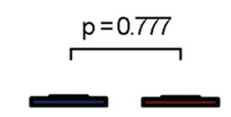

Males

Figure 1. Characterization of the reproductive phenotype of neuron-specific and GABA-specific Prlr KO mice. A, Cre-negative control female mice (Prl/ox/lox) and GABA-specific Prlr KO (Prlrox/lox/VGat-Cre) mice had normal estrous cycles, whereas neuron-specific Prlr KO mice (Prllox/lox/CamK-Cre) showed repetitive pseudopregnancy cycles characterized by prolonged periods in diestrus. The number of transitions from diestrus to estrus ("estrous cycles") are quantified for $n=5-8$ animals per genotype, showing a significant reduction in cycle number in neuron-specific Prlr KO, but not GABA-specific Prlr KO, mice over a $15 \mathrm{~d}$ period. Representative examples of estrous cycles in the three groups are also shown. $\boldsymbol{B}$, Female neuron-specific Prlr KO mice took $\sim 6$ times longer to mate $(n=21)$ compared with Cre-negative controls $(n=11)$, wild-type C57BL/6J (B6;n=9), and GABA-specific Prlr KO $(n=16)$ mice. Different letters indicate significantly different groups $(p<0.001)$. C, There was no difference in gestation length between any of the groups. $\boldsymbol{D}$, Both male and female neuron-specific Prlr K0 mice were markedly hyperprolactinemic compared with Cre-negative controls, whereas prolactin levels were not different between GABA-specific Prlr KO mice and Cre-negative controls.

cells were fewer, and they were notably absent in the VMN. The induction of eGFP expression in the GABA-specific Prlr KO mice was accompanied by a loss of prolactin-induced pSTAT5 labeling in most regions (Fig. 3B); however, when formally quantified, only in the AVPV and MEA were overall levels of pSTAT5 labeling significantly suppressed compared with Cre-negative $\left(\right.$ Prll $\left.^{\text {lox/lox }}\right)$ control mice (Fig. 3B,C; for the AVPV, $t(9)=1.95$, $p=0.041, t$ test; for the MEA, $t(8)=4.48, p=0.001, t$ test $)$, suggesting that in most areas GABA neurons made up only a small subset of the prolactin-responsive neurons present. In the MeA, however, prolactin-induced pSTAT5 was almost completely absent in the GABA-specific Prlr KO mice.

As these data provided the first comprehensive description of prolactin-sensitive GABAergic neurons in the brain, we sought to 
A
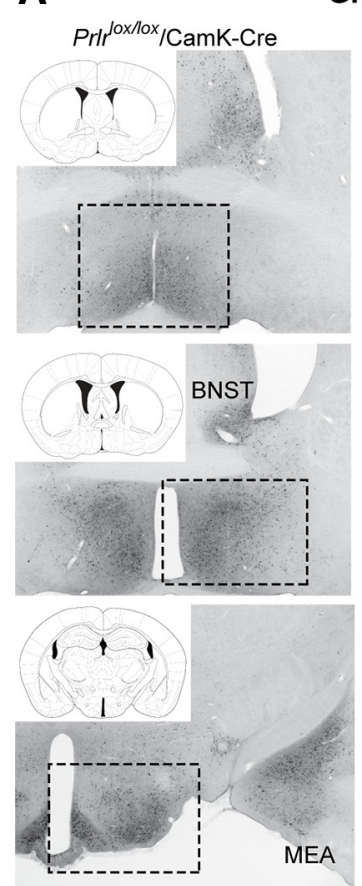

GFP
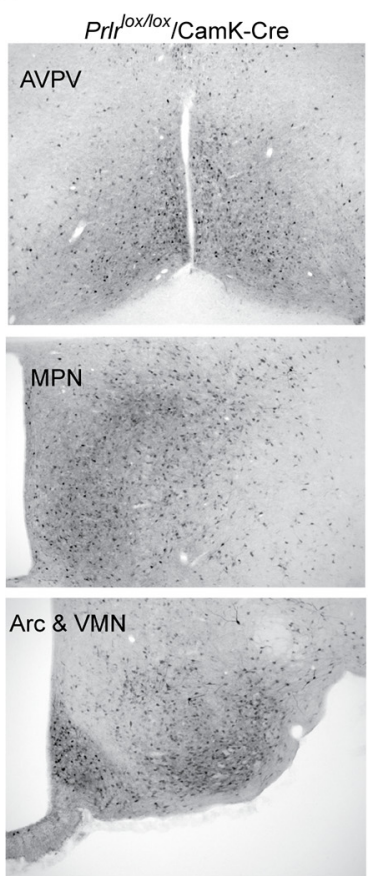

B
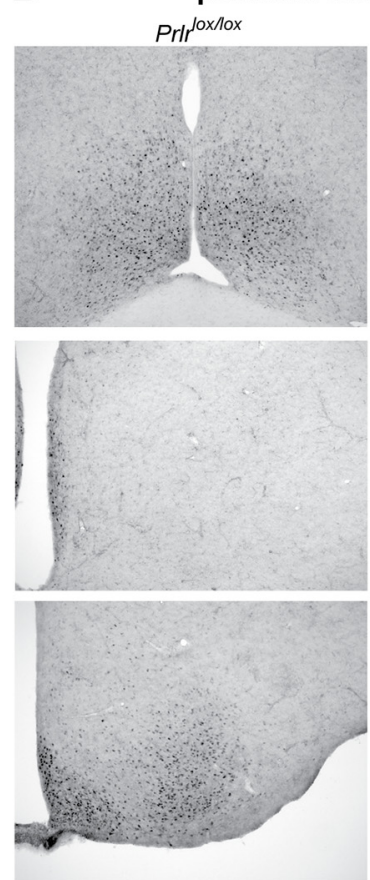

prolactin-induced pSTAT5

Prlrox/lox /CamK-Cre
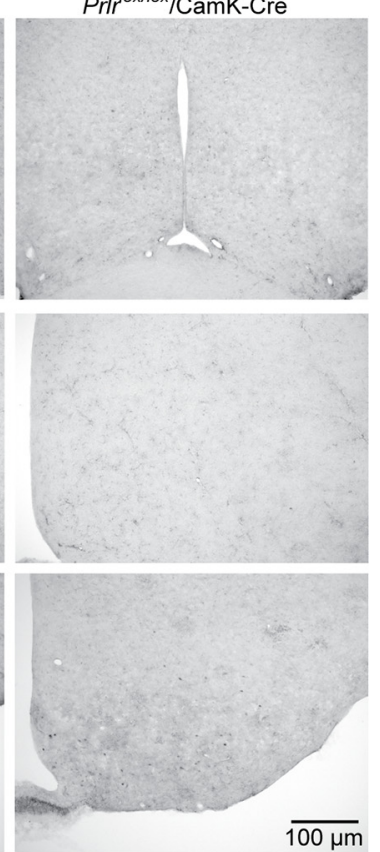

C

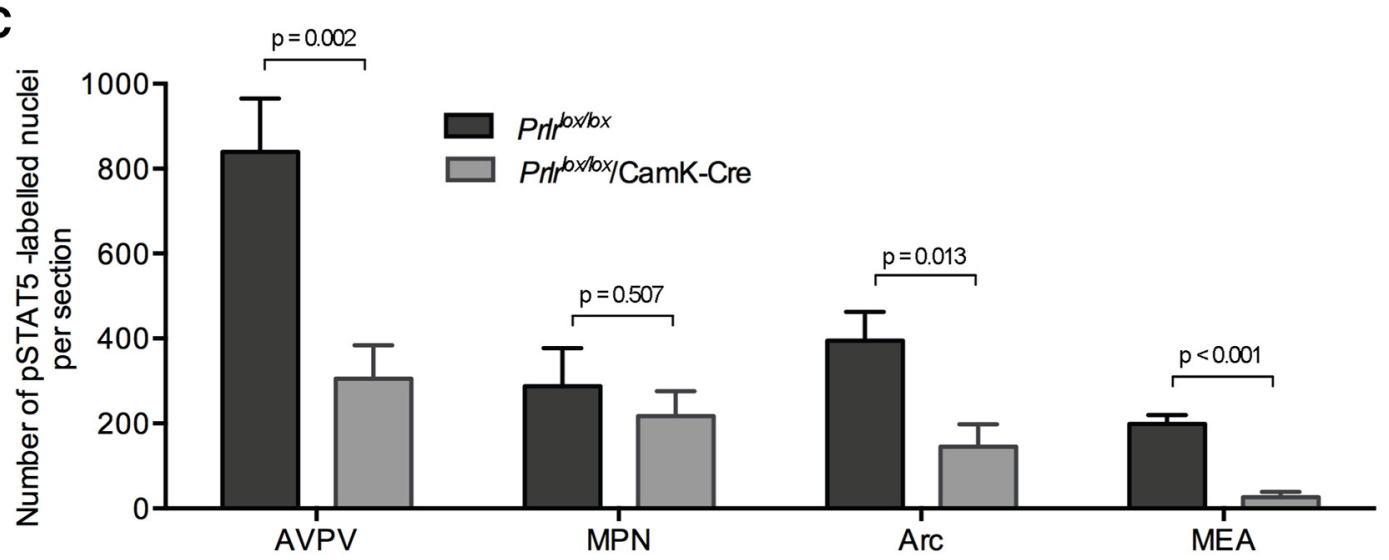

D

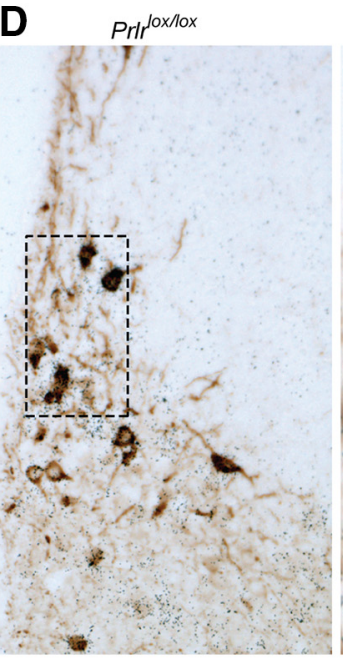

PrIr ${ }^{\text {lox/10x }}$

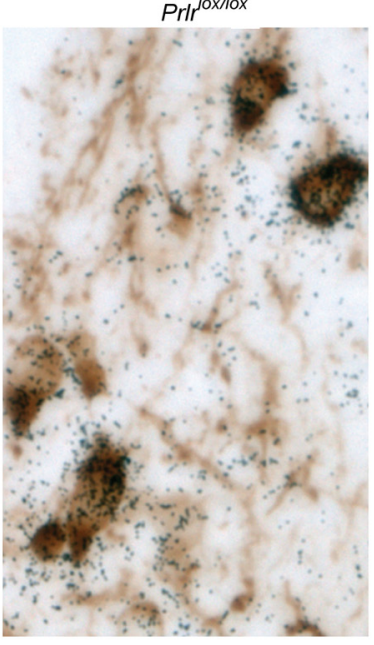

Prlr ${ }^{\text {lox/lox } / C a m K-C r e ~}$

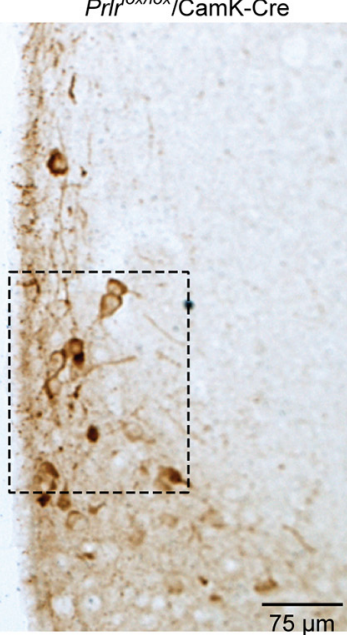

Prllox/lox $/$ CamK-Cre

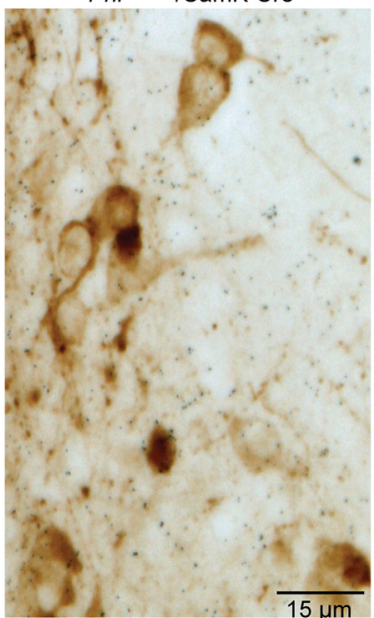

Figure 2. Widespread deletion of Prlr throughout the hypothalamus. A, Expression of eGFP in the neuron-specific Prlr KO (Prlfox/lox/CamK-Cre) mice in the AVPV, MPN, Arc, VMN, and MEA is indicative of the recombination of the targeting construct and deletion of the Prlr gene. $\boldsymbol{B}$, Prolactin-induced pSTAT5 (black nuclear staining) in the same regions, demonstrating functional loss of Prlr signaling in the neuron-specific Prlr KO mice compared with the Cre-negative controls (Prllox/lox). C, Numbers of cells showing prolactin-induced pSTAT5 are quantified in males and females ( $n=6$ or 7 mice per genotype). $\boldsymbol{D}$, Dual in situ hybridization/immunohistochemistry for Prlr mRNA (black dots formed by silver grains in photographic emulsion) and TH (brown cytoplasmic staining, a marker of dopamine neurons) in the arcuate nucleus. The high levels of Prlr mRNA expressed by arcuate dopaminergic neurons in Cre-negative controls is completely lost in the neuron-specific Prlr K0 mice (C). 
A
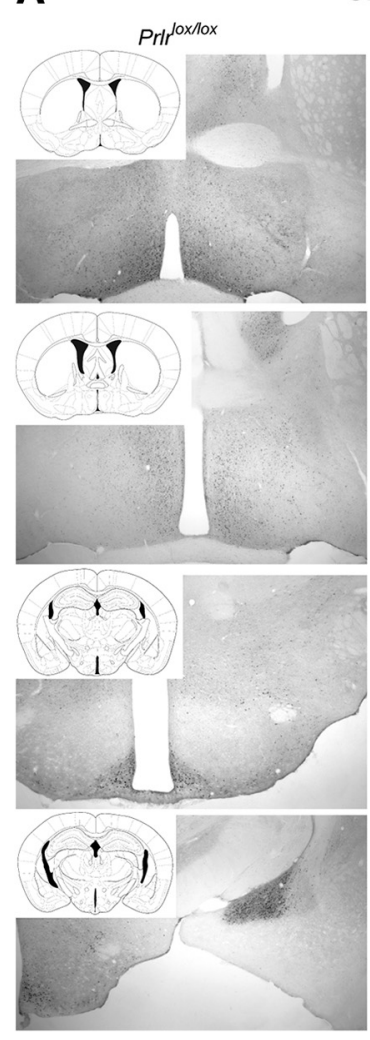

GFP
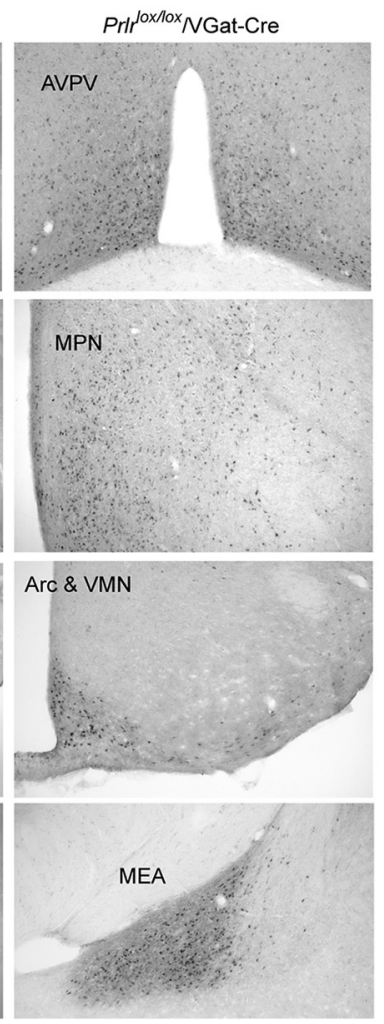

B
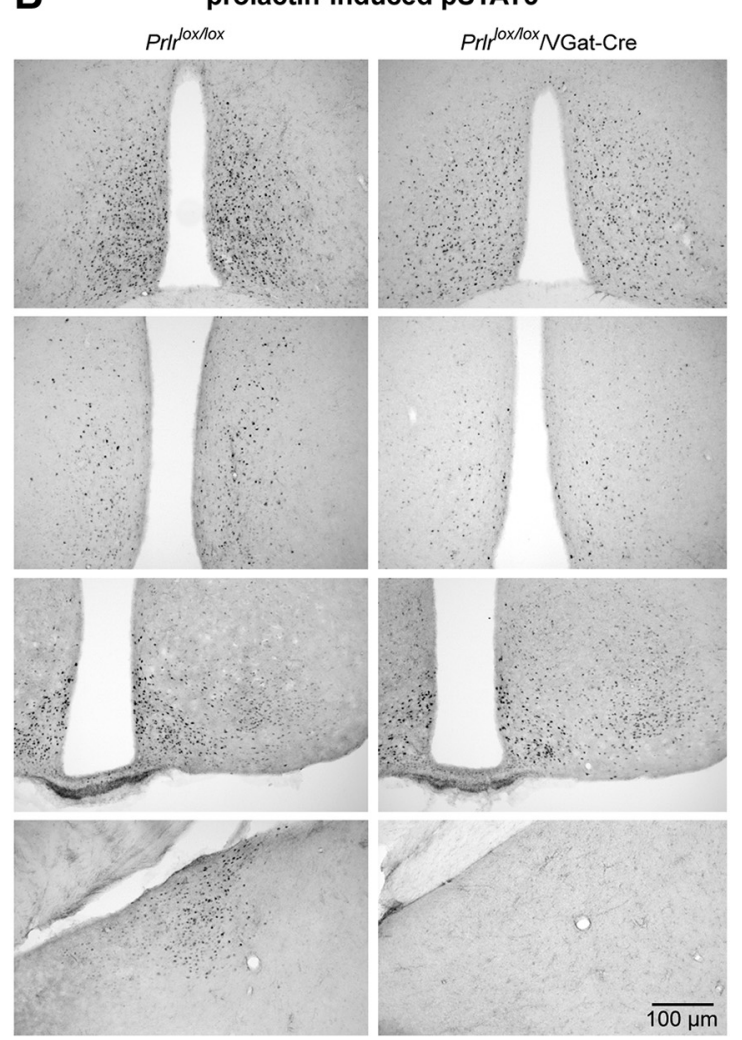

C

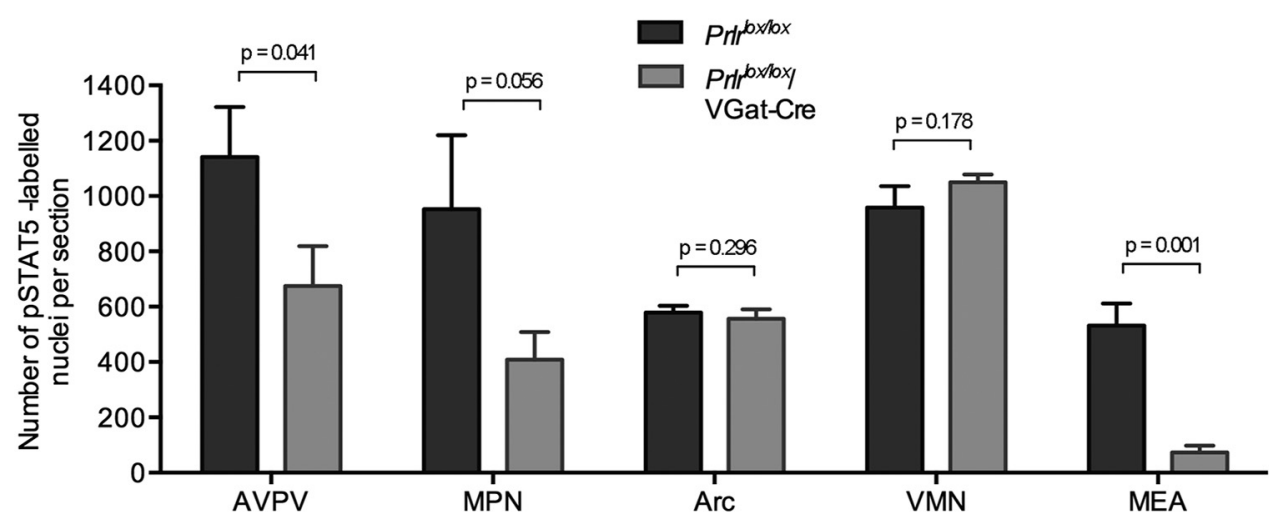

Figure 3. Extensive expression of Prlr in GABAergic neurons in the hypothalamus. A, Expression of eGFP in the GABA-specific Prlr KO (Prlrox/lox/VGat-Cre) mice in the AVPV, MPN, Arc, VMN, and MEA is indicative of the recombination of the targeting construct and deletion of the Prlr gene in GABAergic neurons. B, Prolactin-induced pSTAT5 (black nuclear staining) in the same regions, demonstrating functional loss of Prlr signaling in the GABA-specific Prlr KO mice compared with the Cre-negative controls (Prlrox/lox). C, Numbers of cells showing prolactin-induced pSTAT5 are quantified in females ( $n=4-6$ mice per genotype).

confirm the conditional knock-out data using two additional approaches. First, we crossed the Prll ${ }^{l o x / l o x} /$ VGat-Cre mice onto a Credependent tdTomato reporter mouse to visualize endogenous GABA expression (Fig. $4 A-C$ ). The data showed that VGat-Creinduced GFP expression was occurring in a subset of VGattdTomato neurons in most regions (e.g., AVPV and arcuate nucleus; Fig. $4 A$ and Fig. $4 B$, respectively). Prolactin-induced pSTAT5 could still be detected in most regions, but only in non-tomato-labeled cells, indicating a significant population of non-GABAergic neurons that expressed Prlr in each region. However, in the MEA, VGat-Creinduced GFP was expressed in $>90 \%$ of the tomato-labeled cells, and there was a complete loss of prolactin-induced pSTAT5 labeling in the MEA of Prll $r^{\text {lox/lox}} /$ VGat-Cre mice (Fig. 4C). Finally, we used double-label in situ hybridization to examine Prlr mRNA expression in GABAergic neurons expressing GAD mRNA in the MEA from wild-type mice (Fig. 4D-F). Consistent with the immunofluorescent data, all Prlr mRNA labeling in the MEA was restricted to GADexpressing neurons (Fig. 4D), and this expression was completely deleted in GABA-specific Prlr KO ( $\left.\mathrm{Prll}^{\text {lox/lox}} / \mathrm{VGat}-\mathrm{Cre}\right)$ mice. Although prolactin-induced pSTAT5 labeling has previously been observed in the MEA of mice, the identity of these neurons was unknown. The present data suggested that this population was exclusively GABAergic.

\section{A subpopulation of arcuate nucleus dopamine neurons coexpress GABA}

To evaluate whether arcuate dopamine neurons specifically expressed vGat, we used double-label immunohistochemistry to detect 

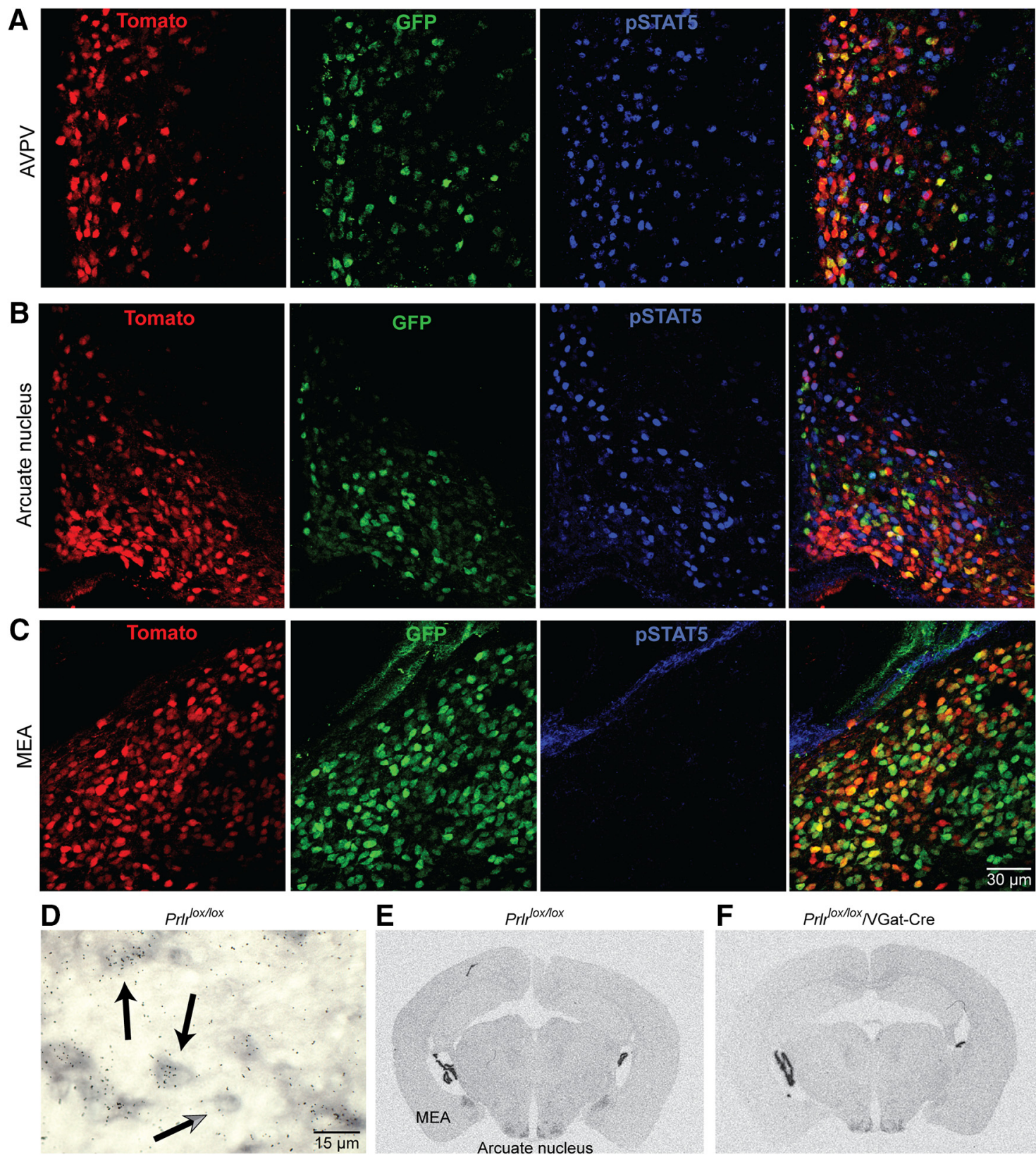

Figure 4. Distribution of prolactin-sensitive GABAergic neurons. $\boldsymbol{A}-\boldsymbol{C}$, Immunofluorescent labeling in the AVPV $(\boldsymbol{A})$, arcuate nucleus $(\boldsymbol{B})$, and MEA $(\boldsymbol{C})$ of $P$ Pr/lox/lox $/ V G$ at-Cre/td-tomato mice where endogenous tomato labeling (red) shows VGat-Cre expression (indicating GABAergic neurons), eGFP labeling (green) shows GABAergic neurons that previously expressed Prlr, and prolactin-induced pSTAT5 labeling (blue) indicates cells that still respond to prolactin after Prlr have been removed from GABAergic neurons. There is a complete absence of pSTAT5 labeling in the MEA of GABA-specific (Prlrox/lox/VGat-Cre) Prlr KO mice (C). D, Representative image of dual-label in situ hybridization for Gad 65/67 mRNA (cellular DIG stain) and Pr/r mRNA (shown as black silver grains) in the MEA of a Cre-negative control (Prlrox/lox $)$. Black arrows indicate Prlr mRNA expression in GABAergic neurons, while grey arrows indicate GABAergic neurons that do not express Prlr mRNA. $\boldsymbol{E}, \boldsymbol{F}$, Autoradiograms showing Prlr mRNA expression in the MEA and Arc of a Cre-negative control $(\boldsymbol{E})$ and a GABA-specific Prlr K0 mouse $(\boldsymbol{F})$. There is total loss of Pr/r mRNA expression in the MEA of the GABA-specific Prlr KO mouse, whereas Prlr mRNA remains largely comparable with control in the arcuate and ventromedial nucleus.

TH and pSTAT5 in VGat-Cre tdTomato reporter mice (Fig. 5A). tdTomato-labeled GABAergic neurons could be detected throughout the arcuate nucleus. Some of the TH-positive cells also expressed tdTomato, and hence could be considered GABAergic, although there were many that did not. Prolactin-induced pSTAT5 could be detected in almost all TH cells, whether or not they were also VGAT positive. In addition, there were some VGat-positive cells that responded to prolactin that were not TH-positive, as well as some pSTAT-positive cells that were not TH- or VGat-positive. We have previously reported that almost all arcuate TH-positive neurons (dopamine) show prolactin-induced pSTAT5 labeling in female mice (Brown et al., 2012). Although almost all prolactin-induced pSTAT5 labeling was absent in neuron-specific Prlr KO (Prl ${ }^{\text {lox/lox }} /$ CamK-Cre) mice, $48.0 \pm 2.9 \%$ of TIDA neurons showed prolactin-induced pSTAT5 labeling in GABA-specific Prlr KO $\left(\operatorname{Prll}^{\text {lox/lox }} / \mathrm{VGat}\right.$-Cre $)$ mice $\left(F_{(3,22)}=30.73, p<0.001\right.$, one-way ANOVA; Fig. $5 B, C$ ). There was no difference in the number of TH-labeled neurons in either neuron-specific or GABA-specific Prlr KO mice compared with controls $\left(F_{(3,22)}=0.32, p=0.81\right.$, one-way ANOVA; Fig. 5D). This indicates that approximately half of dopamine neurons in the arcuate nucleus also coexpress GABA and have hence lost the ability to respond to prolactin in the GABA-specific 


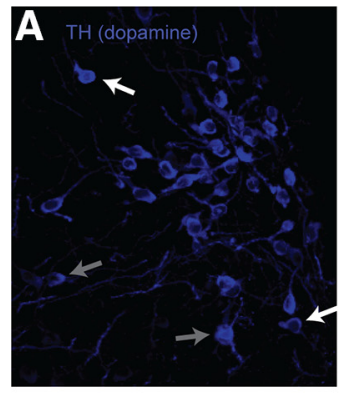

B

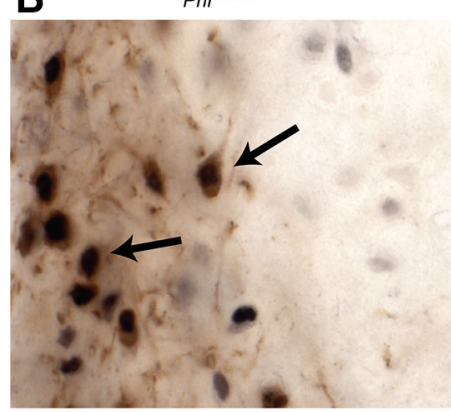

C
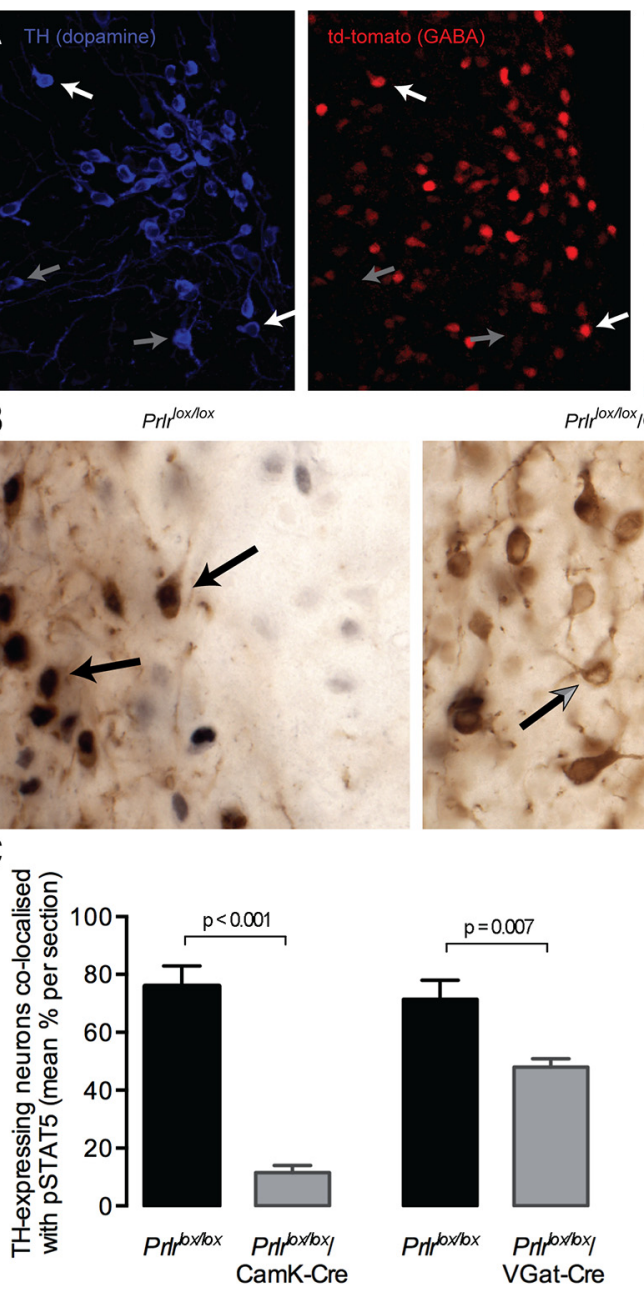
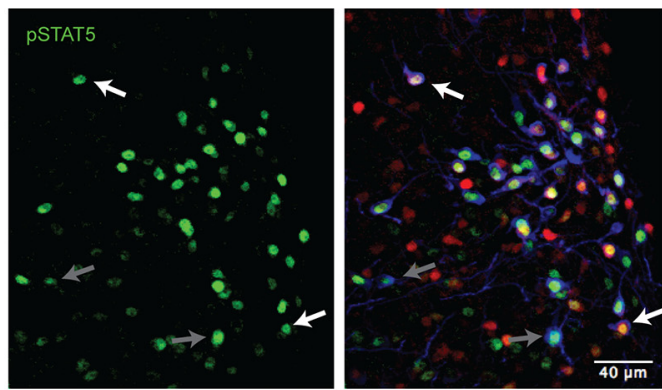

Prir ${ }^{\text {lox } / 10 x}$ NGat-Cre
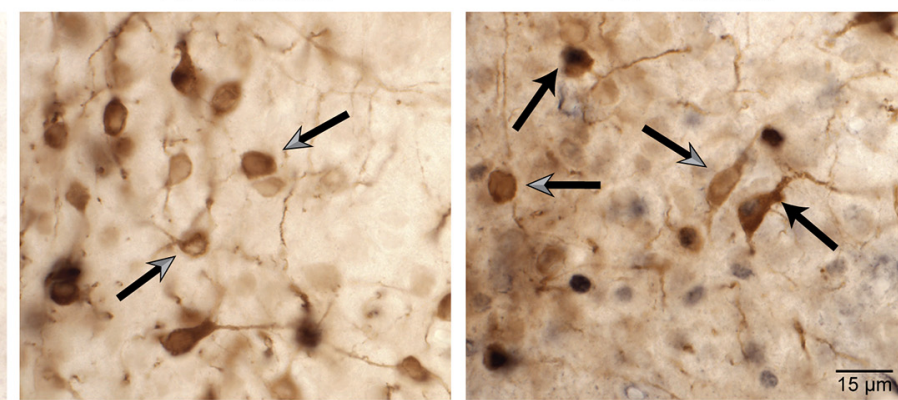

D
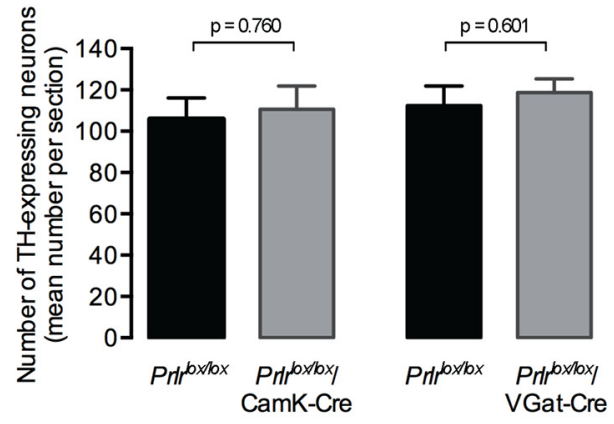

$\mathbf{E}$

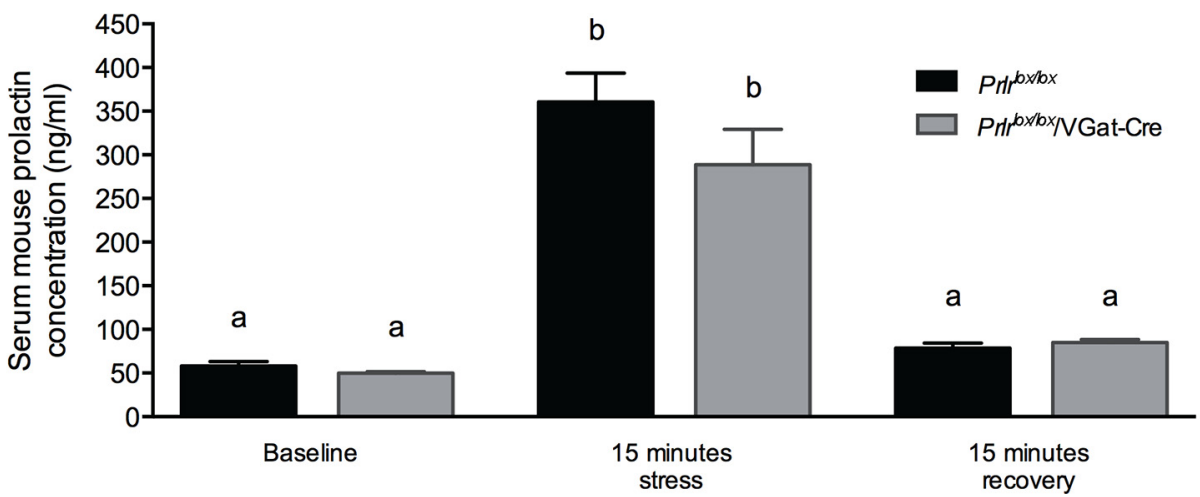

Figure 5. Prolactin regulation of arcuate dopamine neurons. A, Immunofluorescent labeling in the arcuate nucleus of VGat-Cre/td-tomato mice where endogenous tomato labeling (red) shows VGat-Cre expression (indicating GABAergic neurons), TH immunofluorescence (blue) indicates dopamine neurons, and prolactin-induced pSTAT5 labeling (green) indicates prolactin-responsive cells. Almost all TH-positive (dopamine) cells and many tdTomato (GABAergic) cells are positive for prolactin-induced pSTAT5. There are many examples of colocalization of GABA (td-tomato), dopamine (TH), and prolactin-induced pSTAT5 (white arrows). In addition, however, many TH-positive cells are negative for tdTomato, representing non-GABAergic dopamine neurons (grey arrows). These remain prolactin-responsive, as indicated by positive label for pSTAT5. Finally, there are some prolactin-responsive cells that are neither dopaminergic nor GABAergic (green only). $\boldsymbol{B}$,

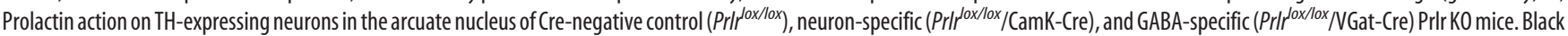
arrowheads indicate dopamine neurons colocalized with PSTAT5. Gray arrowheads indicate TH neurons that do not show pSTAT5 labeling. There is near-complete loss of pSTAT5 labeling in dopamine neurons in the neuron-specific Prlr KO mice and partial loss in the GABA-specific Prlr KO mice ( $($ ). There was no change in the total number of TH-expressing neurons in the arcuate nucleus between genotypes $(\boldsymbol{D})$. $\boldsymbol{E}$, Negative feedback regulation of prolactin levels following restraint stress is unchanged in GABA-specific Prlr K0 mice $(n=6)$, compared with Cre-negative controls $(n=$ $6-8)$. Different letters indicate significantly different groups $(p<0.001)$.

Prlr KO. Despite this, we had previously seen that the negative feedback regulation of prolactin secretion was unaffected in the GABAspecific Prlr KO mice (Fig. 1D). That result had been under basal conditions of low prolactin secretion. Hence, to determine whether feedback regulation of prolactin secretion remained normal in the GABA-specific Prlr KO mice under stimulated conditions, we examined the profile of prolactin secretion in response to acute stress. An acute restraint stress for $15 \mathrm{~min}$ led to significantly elevated levels of 
serum prolactin in both control and GABA-specific Prlr KO mice (from an unstressed $57.9 \pm 5.4 \mathrm{ng} / \mathrm{ml}$ to a stressed $360.7 \pm 32.9$ $\mathrm{ng} / \mathrm{ml}$ following a $15 \mathrm{~min}$ stress in control mice, and from an unstressed $49.9 \pm 1.6 \mathrm{ng} / \mathrm{ml}$ to a stressed $288.8 \pm 40.6 \mathrm{ng} / \mathrm{ml}$ following a $15 \mathrm{~min}$ stress in $\mathrm{Prlr}^{\text {lox/lox}} / \mathrm{VGat}-\mathrm{Cre}$ mice $\left(F_{(2,36)}=78.94\right.$, $p<0.001$, two-way ANOVA; Fig. 5E). Interestingly, in both Cre negative control mice $\left(\mathrm{Prlr}^{\text {lox/lox }}\right)$ and in GABA-specific KO

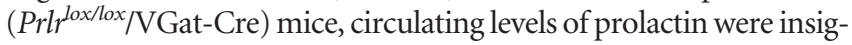
nificantly different from baseline levels within $15 \mathrm{~min}$ of restraint stress ceasing (Fig. $5 E$; there was no difference between genotypes; $F_{(1,36)}=1.487, p=0.23$, two-way ANOVA), indicating that prolactin-sensitivity in only $50 \%$ of arcuate dopamine neurons is sufficient for normal negative feedback regulation of prolactin secretion both under basal and stimulated conditions.

\section{The GABA-expressing population of dopamine neurons represent a functional subpopulation that may be distinct from the tuberoinfundibular dopamine neurons}

The surprising data that knocking out Prlr in the large proportion of arcuate dopamine neurons that coexpress GABA had no effect on the feedback regulation of prolactin secretion prompted us to investigate whether there might be differential expression of TH/dopamine and VGat at the level of the TIDA nerve terminal in the median eminence. To investigate this question, we examined the pattern of $\mathrm{TH}$ staining in the median eminence in VGat-Cre-tdTomato mice. Although there was extensive expression of vGat/tdTomato in the external zone of the median eminence, there was very little colocalization with $\mathrm{TH}$ immunoreactivity (marking the nerve terminals of the TIDA neurons) (Fig. 6A-D). As a positive control, we also examined the pattern of $\mathrm{TH}$ staining in mice with an EGFP reporter in dopamine-transporter expressing cells (DAT-Cre). Again, there was extensive expression of GFP in the median eminence of DATpositive cells. In contrast to the expression driven by VGat, however, DAT-reporting GFP expression was completely colocalized with $\mathrm{TH}$ immunoreactivity (Fig. 6E-H).

\section{Discussion}

Our data demonstrate that there are at least two functional subpopulations of dopamine neurons in the arcuate nucleus, with $\sim 50 \%$ of these neurons expressing GABA. The dopamine neurons that express GABA are not necessary for the feedback regulation of prolactin secretion, and may not project to the median eminence, perhaps rather serving as local interneurons regulating the function of arcuate circuits (Zhang and van den Pol, 2015). In contrast, dopamine neurons that do not express GABA could perhaps be considered true TIDA neurons that project to the median eminence and are necessary for the regulation of prolactin secretion. Loss of Prlr in these neurons resulted in complete failure of negative feedback and consequent hyperprolactinemia. Although the dopamine/ GABA neurons are not required for the feedback regulation of prolactin secretion, most of these cells do express Prlr, and hence could provide a mechanism by which prolactin could act within the arcuate nucleus to regulate a number of physiological processes (Grattan and Akopian, 2016).

The arcuate dopamine neurons have been widely considered to be a uniform group of neurons, the TIDA neurons, that project to the median eminence and control prolactin secretion. Some early evidence had already suggested heterogeneity, as a subset of $\mathrm{TH}$-positive neurons in the ventrolateral parts of the nucleus, were reported to lack aromatic L-amino acid decarboxylase, and hence not produce dopamine (Meister et al., 1988; Okamura et al., 1988; Ugrumov et al., 2002). In addition, based on anatomical evidence of differential innervation of the infundibulum or pituitary gland, the arcuate dopamine neurons have been anatomically subdivided into three populations: the TIDA, tuberohypophyseal and periventricular hypophyseal dopaminergic neurons (DeMaria et al., 1999). TIDA neurons arise from the dorsomedial arcuate nucleus and project to the external zone of the median eminence (Björklund et al., 1973), whereas tuberohypophyseal dopaminergic neurons originate in the rostral arcuate nucleus and project to the intermediate and neural lobes of the pituitary gland (Fuxe, 1964; Holzbauer and Racké, 1985) and periventricular hypophyseal dopaminergic arise more rostrally in the periventricular nucleus, with axons terminating solely in the intermediate lobe of the pituitary gland (Goudreau et al., 1992). While anatomically distinct, there is considerable overlap in the dendritic fields of these populations of arcuate dopamine neurons (van den Pol et al., 1984), and they are widely considered functionally similar, in terms of their regulation and pattern of dopamine release (Demaria et al., 2000). A recent report has provided evidence that even this view of a common neuroendocrine function (releasing dopamine into blood to control the pituitary gland) was also overly simplistic. Two subpopulations were identified within the dorsomedial arcuate nucleus based on differential electrophysiological characteristics, and optogenetic activation of arcuate dopamine neurons as a population (using the DAT promoter) resulted in extensive local release of GABA within the arcuate nucleus (Zhang and van den Pol, 2015). This suggested that arcuate dopamine neurons do not simply project to the median eminence but also have a local interneuron function. Our data are consistent with this observation and extend it by distinguishing the neuroendocrine and interneuron functions as being mediated by distinct populations, based on the GABAergic phenotype.

Both male and female neuron-specific Prlr $\mathrm{KO}$ mice were markedly hyperprolactinemic, due to loss of Prlr on the TIDA neurons that normally inhibit prolactin secretion. Prolactin stimulates dopamine release from these neurons and thereby inhibits its own secretion by short-loop negative feedback (Grattan and Kokay, 2008). In the absence of Prlr expression on these neurons, dopamine release would be markedly reduced (Arbogast and Voogt, 1995), resulting in elevated prolactin secretion. Female neuron-specific Prlr KO mice exhibited normal onset of puberty but had abnormal estrous cycles characterized by prolonged periods in diestrus. This is a predictable consequence of the hyperprolactinemia, with elevated plasma prolactin acting on the corpus luteum formed by the postovulatory follicle to sustain progesterone secretion for $\sim 2$ weeks after each ovulation, establishing recurrent pseudopregnancy state (Stocco et al., 2007). The absence of hyperprolactinemia and pseudopregnancy in the GABA-specific Prlr KO mice could be interpreted as functional redundancy, as this resulted in loss of Prlr expression in only $\sim 50 \%$ of arcuate dopamine neurons. However, when coupled with the observation that GABA did not colocalize with $\mathrm{TH}$ in the median eminence, a more likely interpretation is that this population of neurons are distinct from the TIDA neurons, and are not directly involved in the regulation of prolactin secretion. While there is extensive GABAergic innervation of the median eminence, it appears that VGat expression is not in the terminals of TIDA neurons, and may instead represent other neuroendocrine neurons that coexpress GABA, such as somatostatin (Toossi et al., 2012) or growth hormone-releasing hormone (Hrabovszky et al., 2005).

CamK-Cre-induced expression of eGFP could be detected by immunohistochemistry throughout the hypothalamus of 


\section{VGat-Cre/td-tomato}
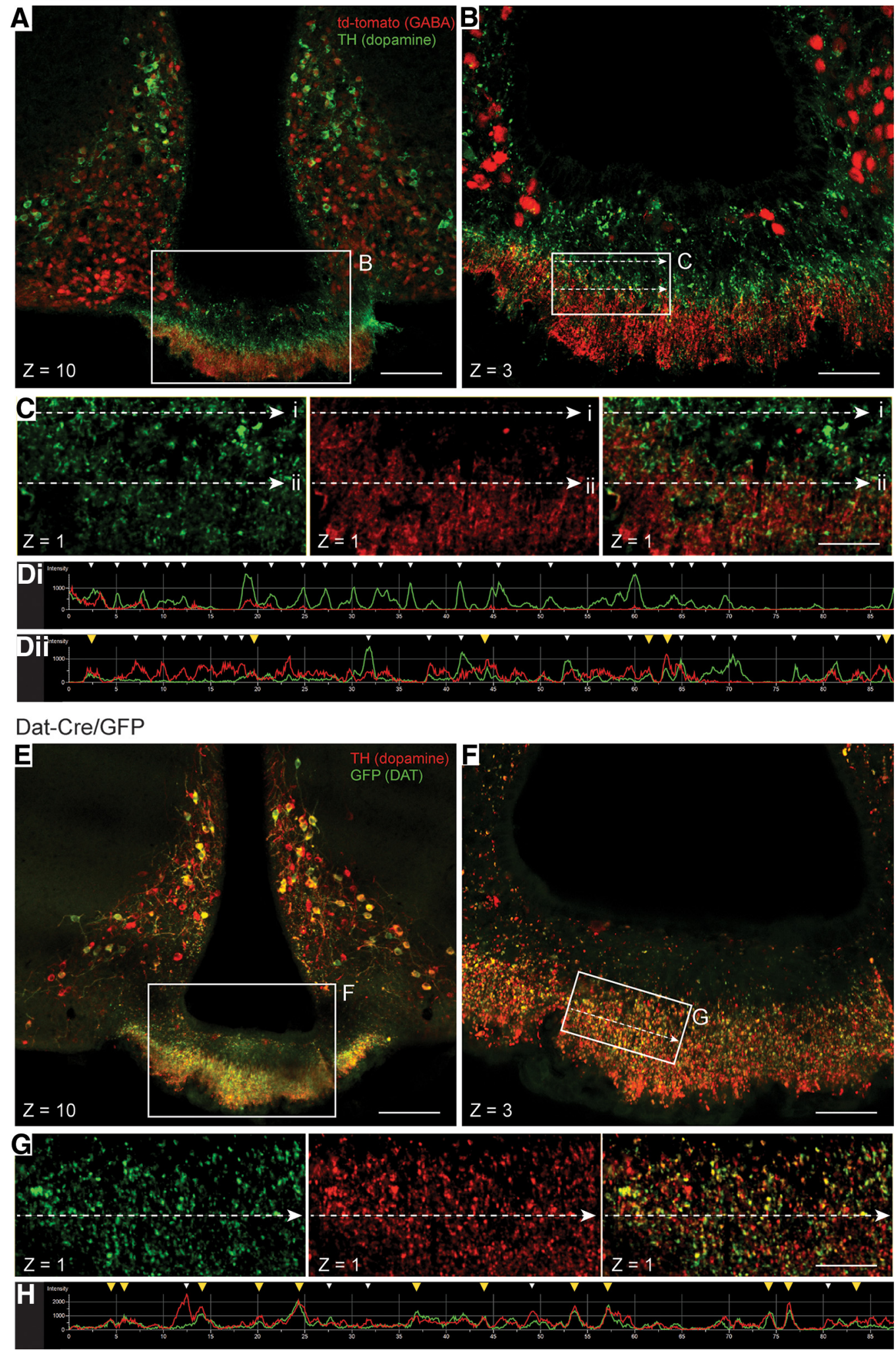

Figure 6. VGat-induced tdTomato labeling is not observed in dopaminergic nerve terminals in the median eminence. $\boldsymbol{A}-\boldsymbol{D}$, Representative confocal images showing coronal section of a vesicular GABA transporter Cre x tdTomato reporter mouse colabeled with TH. $\boldsymbol{B}$, Enlarged image of boxed area in $\boldsymbol{A}$ showing endogenous VGat-tom (red) and TH-immunoreactive (green) labeling in the median eminence. C, Single z-plane split-channel enlarged images of boxed area in $\boldsymbol{B}$. Di, Dii, Intensity profile extracted from top and bottom intensity measurement line (dotted arrows in $\boldsymbol{C}$ ), respectively, across the plane section from left to right. Yellow arrowheads indicate shared locus between red and green staining. White arrowheads indicate only single staining. $\boldsymbol{E}-\boldsymbol{H}$, Representative confocal images showing coronal section of a dopamine transporter $\times$ green fluorescence protein (DAT-GFP) mouse. $\boldsymbol{E}$, Many (but not all) TH-immunoreactive cells (red) were colabeled with DAT-GFP (green). $\boldsymbol{F}$, Enlarged image of boxed area in $\boldsymbol{E}$ depicting the median eminence with colocalization of TH and DAT-GFP. $\boldsymbol{G}$, Single z-plane split-channel enlarged images of boxed area in $\boldsymbol{F}$. $\boldsymbol{H}$, Intensity profile extracted from the intensity measurement line (dotted arrows in $\mathbf{G}$ ) across the plane section from left to right. Yellow arrowheads indicate shared locus between red and green staining. White arrowheads indicate only single staining. Z, Z-stack. Scale bars: $A, E, 100 \mu \mathrm{m} ; \boldsymbol{B}, \boldsymbol{F}, 50 \mu \mathrm{m} ; \boldsymbol{C}, \mathbf{G}, 10 \mu \mathrm{m}$. 
neuron-specific Prlr KO mice. The distribution of eGFP was consistent with the known distribution of Prlr expression in the mouse brain (Brown et al., 2010; Furigo et al., 2014), with prominent expression in the rostral preoptic area and bed nucleus of the stria terminalis, the MPN, ventromedial hypothalamic nucleus, and arcuate nucleus of the hypothalamus. As CamK is expressed postnatally in forebrain neurons, but not in glial cells (Ouimet et al., 1984; Burgin et al., 1990), this pattern of eGFP expression was indicative of a loss of Prlr in forebrain neurons. Using prolactin-induced PSTAT5 as a marker for prolactin action in the brain (Brown et al., 2010), we were able to demonstrate a marked loss of prolactin action consistent with a loss of Prlr expression in these nuclei, confirming the utility of this gene-targeting approach to investigation of prolactin action in the brain. The MPN was an exception, as we observed significant Cre-induced GFP expression, but minimal loss of pSTAT5. It is likely this is because, despite relatively high levels of Prlr mRNA in this nucleus, prolactin-induced PSTAT5 in the MPN is low in nonpregnant females but markedly upregulated during lactation (Brown et al., 2011). It is likely that, if we had looked at lactating animals, the amount of pSTAT5 detected would be reduced from a higher starting point. Despite the clear efficacy of the approach, some pSTAT5 remained detectable in several regions. This is likely due to the fact that CamK-Cre-mediated recombination did not occur in some prolactin-responsive cells. It is well established that this Cre-line is forebrain neuron specific; but even within the forebrain, Cre is not expressed in all neurons, and in particular, expression in the hypothalamus is considered sporadic (Casanova et al., 2001). Alternatively, it is also possible that some other cytokine might be activating STAT5 in those regions. For example, growth hormone-induced pSTAT has recently been characterized in the hypothalamus (Furigo et al., 2016).

Using the VGat-Cre, we also observed widespread expression of GFP, indicative of numerous populations of prolactinsensitive GABAergic neurons throughout the hypothalamus. These are exciting new data, as they offer strong evidence that GABAergic neurons might mediate some of the pleiotropic actions of prolactin in the brain (Grattan and Kokay, 2008). For example, GABA neurons have recently been implicated in the prolactin-induced suppression of pulsatile LH secretion in rats (Grachev et al., 2015), an action likely to contribute to the suppression of fertility during lactation. These mice provide a novel tool to investigate such mechanisms. In most of the brain regions examined, GABAergic neurons made up a subset of prolactinresponsive cells, and a number of prolactin-responsive neurons remained after deletion of Prlr in GABAergic neurons. By contrast, in the VMN, there were no prolactin-sensitive GABAergic neurons, consistent with the low levels of GABAergic neurons in this nucleus. In the posterodorsal medial amygdala, however, all prolactin-responsive neurons were GABAergic. It will be of interest to determine the role of prolactin in this nucleus.

The development of mice allowing conditional deletion of Prlr in specific neuronal populations in the brain has enabled novel approaches to identify and interrogate the function of prolactin-sensitive neurons in the brain. In the arcuate nucleus, in particular, we have been able to separate two subpopulations of dopamine neurons, based on the coexpression of VGat, and demonstrate anatomical and functional differences between these populations. Perhaps more importantly, the mice provide the opportunity to target subpopulations of prolactin-sensitive cells, and investigate the mechanisms mediating the multiple actions of prolactin in the brain, as well as in other tissues.

\section{References}

Arbogast LA, Voogt JL (1995) Hypoprolactinemia decreases tyrosine hydroxylase activity in the tuberoinfundibular dopaminergic neurons acutely by protein dephosphorylation and chronically by changes in gene expression. Endocrine 3:801-806. CrossRef Medline

Arbogast LA, Voogt JL (1996) The responsiveness of tuberoinfundibular dopaminergic neurons to prolactin feedback is diminished between early lactation and midlactation in the rat. Endocrinology 137:47-54. CrossRef Medline

Bäckman CM, Malik N, Zhang Y, Shan L, Grinberg A, Hoffer BJ, Westphal H, Tomac AC (2006) Characterization of a mouse strain expressing Cre recombinase from the $3^{\prime}$ untranslated region of the dopamine transporter locus. Genesis 44:383-390. CrossRef Medline

Bernard V, Young J, Chanson P, Binart N (2015) New insights in prolactin: pathological implications. Nat Rev Endocrinol 11:265-275. CrossRef Medline

Binart N, Helloco C, Ormandy CJ, Barra J, Clément-Lacroix P, Baran N, Kelly PA (2000) Rescue of preimplantatory egg development in prolactin receptor-deficient mice after progesterone administration. Endocrinology 141:2691-2697. CrossRef Medline

Björklund A, Moore RY, Nobin A, Stenevi U (1973) The organization of tubero-hypophyseal and reticulo-infundibular catecholamine neuron systems in the rat brain. Brain Res 51:171-191. CrossRef Medline

Brown RS, Kokay IC, Herbison AE, Grattan DR (2010) Distribution of prolactin-responsive neurons in the mouse forebrain. J Comp Neurol 518:92-102. CrossRef Medline

Brown RS, Herbison AE, Grattan DR (2011) Differential changes in responses of hypothalamic and brainstem neuronal populations to prolactin during lactation in the mouse. Biol Reprod 84:826-836. CrossRef Medline

Brown RS, Piet R, Herbison AE, Grattan DR (2012) Differential actions of prolactin on electrical activity and intracellular signal transduction in hypothalamic neurons. Endocrinology 153:2375-2384. CrossRef Medline

Burgin KE, Waxham MN, Rickling S, Westgate SA, Mobley WC, Kelly PT (1990) In situ hybridization histochemistry of $\mathrm{Ca}^{2+} /$ calmodulin-dependent protein kinase in developing rat brain. J Neurosci 10:1788-1798. Medline

Capozzi A, Scambia G, Pontecorvi A, Lello S (2015) Hyperprolactinemia: pathophysiology and therapeutic approach. Gynecol Endocrinol 31: 506-510. CrossRef Medline

Casanova E, Fehsenfeld S, Mantamadiotis T, Lemberger T, Greiner E, Stewart AF, Schütz G (2001) A CamKIIalpha iCre BAC allows brain-specific gene inactivation. Genesis 31:37-42. CrossRef Medline

Demarest KT, McKay DW, Riegle GD, Moore KE (1983) Biochemical indices of tuberoinfundibular dopaminergic neuronal activity during lactation: a lack of response to prolactin. Neuroendocrinology 36:130-137. Medline

DeMaria JE, Lerant AA, Freeman ME (1999) Prolactin activates all three populations of hypothalamic neuroendocrine dopaminergic neurons in ovariectomized rats. Brain Res 837:236-241. CrossRef Medline

Demaria JE, Nagy GM, Lerant AA, Fekete MI, Levenson CW, Freeman ME (2000) Dopamine transporters participate in the physiological regulation of prolactin. Endocrinology 141:366-374. CrossRef Medline

Everitt BJ, Hökfelt T, Wu JY, Goldstein M (1984) Coexistence of tyrosine hydroxylase-like and gamma-aminobutyric acid-like immunoreactivities in neurons of the arcuate nucleus. Neuroendocrinology 39:189-191. Medline

Freeman ME, Kanyicska B, Lerant A, Nagy G (2000) Prolactin: structure, function, and regulation of secretion. Physiol Rev 80:1523-1631. Medline

Furigo IC, Kim KW, Nagaishi VS, Ramos-Lobo AM, de Alencar A, Pedroso JA, Metzger M, Donato J Jr (2014) Prolactin-sensitive neurons express estrogen receptor-alpha and depend on sex hormones for normal responsiveness to prolactin. Brain Res 1566:47-59. CrossRef Medline

Furigo IC, Metzger M, Teixeira PD, Soares CR, Donato J Jr (2016) Distribution of growth hormone-responsive cells in the mouse brain. Brain Struct Funct. Advance online publication. Retrieved Apr. 12, 2016. doi: 10.1007/s00429-016-1221-1. CrossRef Medline

Fuxe K (1964) Cellular localization of monoamines in the median eminence and the infundibular stem of some mammals. Z Zellforsch Mikrosk Anat 61:710-724. Medline

Goudreau JL, Lindley SE, Lookingland KJ, Moore KE (1992) Evidence that hypothalamic periventricular dopamine neurons innervate the intermediate lobe of the rat pituitary. Neuroendocrinology 56:100-105. Medline Grachev P, Li XF, Goffin V, O’Byrne KT (2015) Hypothalamic prolactin 
regulation of luteinizing hormone secretion in the female rat. Endocrinology 156:2880-2892. CrossRef Medline

Grattan DR (2001) The actions of prolactin in the brain during pregnancy and lactation. Prog Brain Res 133:153-171. CrossRef Medline

Grattan DR (2015) 60 years of neuroendocrinology: the hypothalamoprolactin axis. J Endocrinol 226:T101-T122. CrossRef Medline

Grattan DR, Akopian AN (2016) Oscillating from neurosecretion to multitasking dopamine neurons. Cell Rep 15:681-682. CrossRef Medline

Grattan DR, Kokay IC (2008) Prolactin: a pleiotropic neuroendocrine hormone. J Neuroendocrinol 20:752-763. CrossRef Medline

Grattan DR, LeTissier P (2015) Hypothalamic control of prolactin secretion, and the multiple reproductive functions of prolactin. In: Knobil and Neill's physiology of reproduction, Ed 4 (Plant TM, Zelesnik AJ, eds), pp 469-526. New York: Elsevier.

Grattan DR, Xu J, McLachlan MJ, Kokay IC, Bunn SJ, Hovey RC, Davey HW (2001) Feedback regulation of PRL secretion is mediated by the transcription factor, signal transducer, and activator of transcription $5 \mathrm{~b}$. Endocrinology 142:3935-3940. CrossRef Medline

Holzbauer M, Racké K (1985) The dopaminergic innervation of the intermediate lobe and of the neural lobe of the pituitary gland. Med Biol 63:97-116. Medline

Hrabovszky E, Turi GF, Liposits Z (2005) Presence of vesicular glutamate transporter-2 in hypophysiotropic somatostatin but not growth hormone-releasing hormone neurons of the male rat. Eur J Neurosci 21:2120-2126. CrossRef Medline

Kelly MA, Rubinstein M, Asa SL, Zhang G, Saez C, Bunzow JR, Allen RG, Hnasko R, Ben-Jonathan N, Grandy DK, Low MJ (1997) Pituitary lactotroph hyperplasia and chronic hyperprolactinemia in dopamine D2 receptor-deficient mice. Neuron 19:103-113. CrossRef Medline

Kelly PA, Binart N, Lucas B, Bouchard B, Goffin V (2001) Implications of multiple phenotypes observed in prolactin receptor knockout mice. Front Neuroendocrinol 22:140-145. CrossRef Medline

Kokay IC, Grattan DR (2005) Expression of mRNA for prolactin receptor (long form) in dopamine and pro-opiomelanocortin neurones in the arcuate nucleus of non-pregnant and lactating rats. J Neuroendocrinol 17:827-835. CrossRef Medline

Kokay IC, Petersen SL, Grattan DR (2011) Identification of prolactinsensitive GABA and kisspeptin neurons in regions of the rat hypothalamus involved in the control of fertility. Endocrinology 152:526-535. CrossRef Medline

Lerant A, Freeman ME (1998) Ovarian steroids differentially regulate the expression of prolactin receptors in neuroendocrine dopaminergic neuron populations: a double-label confocal microscopic study. Brain Res 802:141-154. CrossRef Medline

Lyons DJ, Hellysaz A, Broberger C (2012) Prolactin regulates tuberoinfundibular dopamine neuron discharge pattern: novel feedback control mechanisms in the lactotrophic axis. J Neurosci 32:8074-8083. CrossRef Medline

Ma FY, Grattan DR, Goffin V, Bunn SJ (2005a) Prolactin-regulated tyrosine hydroxylase activity and messenger ribonucleic acid expression in mediobasal hypothalamic cultures: the differential role of specific protein kinases. Endocrinology 146:93-102. CrossRef Medline

Ma FY, Anderson GM, Gunn TD, Goffin V, Grattan DR, Bunn SJ (2005b) Prolactin specifically activates STAT5b in neuroendocrine dopaminergic neurons. Endocrinology 146:5112-5119. CrossRef Medline

Madisen L, Zwingman TA, Sunkin SM, Oh SW, Zariwala HA, Gu H, Ng LL, Palmiter RD, Hawrylycz MJ, Jones AR, Lein ES, Zeng H (2010) A robust and high-throughput Cre reporting and characterization system for the whole mouse brain. Nat Neurosci 13:133-140. CrossRef Medline

Meister B, Hökfelt T (1988) Peptide- and transmitter-containing neurons in the mediobasal hypothalamus and their relation to GABAergic systems: possible roles in control of prolactin and growth hormone secretion. Synapse 2:585-605. CrossRef Medline

Meister B, Hökfelt T, Steinbusch HW, Skagerberg G, Lindvall O, Geffard M, Joh TH, Cuello AC, Goldstein M (1988) Do tyrosine hydroxylaseimmunoreactive neurons in the ventrolateral arcuate nucleus produce dopamine or only L-dopa? J Chem Neuroanat 1:59-64. Medline

Newey PJ, Gorvin CM, Cleland SJ, Willberg CB, Bridge M, Azharuddin M, Drummond RS, van der Merwe PA, Klenerman P, Bountra C, Thakker RV (2013) Mutant prolactin receptor and familial hyperprolactinemia. N Engl J Med 369:2012-2020. CrossRef Medline

Oberdoerffer P, Otipoby KL, Maruyama M, Rajewsky K (2003) Unidirectional Cre-mediated genetic inversion in mice using the mutant loxP pair lox66/lox71. Nucleic Acids Res 31:e140. CrossRef Medline

Okamura H, Kitahama K, Mons N, Ibata Y, Jouvet M, Geffard M (1988) L-dopa-immunoreactive neurons in the rat hypothalamic tuberal region. Neurosci Lett 95:42-46. CrossRef Medline

Ormandy CJ, Camus A, Barra J, Damotte D, Lucas B, Buteau H, Edery M, Brousse N, Babinet C, Binart N, Kelly PA (1997) Null mutation of the prolactin receptor gene produces multiple reproductive defects in the mouse. Genes Dev 11:167-178. CrossRef Medline

Ouimet CC, McGuinness TL, Greengard P (1984) Immunocytochemical localization of calcium/calmodulin-dependent protein kinase II in rat brain. Proc Natl Acad Sci U S A 81:5604-5608. CrossRef Medline

Romanò N, Yip SH, Hodson DJ, Guillou A, Parnaudeau S, Kirk S, Tronche F, Bonnefont X, Le Tissier P, Bunn SJ, Grattan DR, Mollard P, Martin AO (2013) Plasticity of hypothalamic dopamine neurons during lactation results in dissociation of electrical activity and release. J Neurosci 33: 4424-4433. CrossRef Medline

Saiardi A, Bozzi Y, Baik JH, Borrelli E (1997) Antiproliferative role of dopamine: loss of D2 receptors causes hormonal dysfunction and pituitary hyperplasia. Neuron 19:115-126. CrossRef Medline

Stocco C, Telleria C, Gibori G (2007) The molecular control of corpus luteum formation, function, and regression. Endocr Rev 28:117-149. CrossRef Medline

Toossi H, Del Cid-Pellitero E, Stroh T, Jones BE (2012) Somatostatin varicosities contain the vesicular GABA transporter and contact orexin neurons in the hypothalamus. Eur J Neurosci 36:3388-3395. CrossRef Medline

Ugrumov M, Melnikova V, Ershov P, Balan I, Calas A (2002) Tyrosine hydroxylase- and/or aromatic L-amino acid decarboxylase-expressing neurons in the rat arcuate nucleus: ontogenesis and functional significance. Psychoneuroendocrinology 27:533-548. CrossRef Medline

Van de Kar LD, Blair ML (1999) Forebrain pathways mediating stressinduced hormone secretion. Front Neuroendocrinol 20:1-48. CrossRef Medline

van den Pol AN, Herbst RS, Powell JF (1984) Tyrosine hydroxylaseimmunoreactive neurons of the hypothalamus: a light and electron microscopic study. Neuroscience 13:1117-1156. CrossRef Medline

Vong L, Ye C, Yang Z, Choi B, Chua S Jr, Lowell BB (2011) Leptin action on GABAergic neurons prevents obesity and reduces inhibitory tone to POMC neurons. Neuron 71:142-154. CrossRef Medline

Wen S, Götze IN, Mai O, Schauer C, Leinders-Zufall T, Boehm U (2011) Genetic identification of GnRH receptor neurons: a new model for studying neural circuits underlying reproductive physiology in the mouse brain. Endocrinology 152:1515-1526. CrossRef Medline

Zhang X, van den Pol AN (2015) Dopamine/tyrosine hydroxylase neurons of the hypothalamic arcuate nucleus release GABA, communicate with dopaminergic and other arcuate neurons, and respond to dynorphin, Met-enkephalin, and oxytocin. J Neurosci 35:14966-14982. CrossRef Medline

Zhang Z, Lutz B (2002) Cre recombinase-mediated inversion using lox66 and lox71: method to introduce conditional point mutations into the CREB-binding protein. Nucleic Acids Res 30:e90. CrossRef Medline 